\title{
Effects of whole flaxseed, raw soybeans, and calcium salts of fatty acids on measures of cellular immune function of transition dairy cows
}

\author{
J. R. Gandra, ${ }^{*}$ R. V. Barletta,† R. D. Mingoti, ${ }^{*}$ L. C. Verdurico, ${ }^{*}$ J. E. Freitas Jr., ${ }^{*}$ L. J. Oliveira,ł C. S. Takiya, ${ }^{*}$ \\ J. R. Kfoury Jr.,§ M. C. Wiltbank,† and F. P. Renno*\# \\ *Department of Animal Nutrition and Production, University of Sao Paulo, 13635-900, Pirassununga, Brazil \\ †Department of Dairy Science, University of Wisconsin-Madison, Madison 53706 \\ łDepartment of Animal Sciences, University of Florida, Gainesville 110910 \\ §Department of Surgery, School of Veterinary Medicine and Animal Sciences, University of Sao Paulo, 05508-270, São Paulo, Brazil \\ \#Bursar 1-C of National Council for Technological, 71605-001, Brasilia, Brazil
}

\section{ABSTRACT}

The objective of the current study was to evaluate the effects of supplemental n-3 and n-6 fatty acid (FA) sources on cellular immune function of transition dairy cows. Animals were randomly assigned to receive 1 of 4 diets: control $(\mathrm{n}=11)$; whole flaxseed (n-3 FA source; $\mathrm{n}$ $=11$ ), 60 and $80 \mathrm{~g} / \mathrm{kg}$ of whole flaxseed [diet dry matter (DM) basis] during pre- and postpartum, respectively; whole raw soybeans ( $\mathrm{n}-6$ FA source; $\mathrm{n}=10), 120$ and $160 \mathrm{~g} / \mathrm{kg}$ of whole raw soybeans (diet DM basis) during pre- and postpartum, respectively; and calcium salts of unsaturated FA (Megalac-E, n-6 FA source; n $=10), 24$ and $32 \mathrm{~g} / \mathrm{kg}$ of calcium salts of unsaturated FA (diet DM basis) during pre- and postpartum, respectively. Supplemental FA did not alter DM intake and milk yield but increased energy balance during the postpartum period. Diets containing n- 3 and n- 6 FA sources increased phagocytosis capacity of leukocytes and monocytes and phagocytosis activity of monocytes. Furthermore, n-3 FA source increased phagocytic capacity of leukocytes and neutrophils and increased phagocytic activity in monocytes and neutrophils when compared with n-6 FA sources. Supplemental FA effects on adaptive immune system included increased percentage of T-helper cells, T-cytotoxic cells, cells that expressed IL-2 receptors, and CD62 adhesion molecules. The results of this study suggest that unsaturated FA can modulate innate and adaptive cellular immunity and trigger a proinflammatory response. The n-3 FA seems to have a greater effect on phagocytic capacity and activity of leukocytes when compared with n-6 FA. Key words: adaptive immunity, innate immunity, phagocytosis, unsaturated fatty acid

Received June 16, 2015.

Accepted November 20, 2015.

${ }^{1}$ Corresponding author: francisco.renno@usp.br

\section{INTRODUCTION}

The immune system is composed of innate and adaptive components, in addition to the anatomical and physiological barriers. The components of innate immunity are white blood cells (leukocytes), such as macrophages, neutrophils, and natural killer cells. Innate immunity is the first line of defense against microbial infection (Aderem, 2003). On the other hand, the adaptive immune system is composed of $\mathrm{T}$ and $\mathrm{B}$ lymphocytes, dependent on a clonal system for activation and proliferation, and may take 4 to $7 \mathrm{~d}$ to take effect (Turvey and Broide, 2010).

Fatty acids (FA) can modify the immune response by several mechanisms, which include inhibition of arachidonic acid metabolism, induction of antiinflammatory mediators, modification of intracellular lipids, and activation of nuclear receptors (Yaqoob, 2004; Calder, 2006). Studies in cultured cells, animal models, and human subjects have shown that both the amount and type of FA influence the immune response (Kelley and Rudolph, 2000). For example, Silvestre et al. (2011) observed that feeding calcium salts of safflower oil (rich in n-6 FA) instead of palm oil (rich in saturated FA) during the early postpartum period resulted in greater phagocytic and oxidative burst activity in neutrophils.

The transition from late gestation to early lactation is the period of greatest risk for metabolic and infectious diseases and even death in dairy cows (Grummer et al., 2004). Many types of evidence exist that the immune system is not functioning at an optimal level during the transition period, including decreased mitogen-induced proliferation of lymphocytes (Kimura et al., 2002), decreased antibody response (Mallard et al., 1997), decreased chemotaxis and adhesion molecule expression by neutrophils (Weber et al., 2001), and decreased capacity of neutrophils to kill pathogens (Hammon et al., 2006). One strategy to improve the metabolic status of transition cows is supplementing FA, which can 
increase dietary energy density (Grummer et al., 2004) and modulate immune cell function and inflammatory response (Greco et al., 2015). However, published scientific studies are relatively lacking on the effects of specific FA on cellular immune function in transition cows.

The current study was designed to evaluate the effects of diets containing oilseeds or calcium salts of FA rich in n-3 FA (flaxseed) or n-6 FA (whole raw soybeans and calcium salts of unsaturated FA) on phagocytic capacity and activity and leukocyte profile of dairy cows during the transition period and early lactation. Our hypothesis was that supplemental fat would modulate the immune system in dairy cows during the transition period and the response would depend on the FA source.

\section{MATERIALS AND METHODS}

\section{Animals, Experimental Design, and Diets}

This study was approved by the Bioethics Committee of the School of Veterinary Medicine and Animal Sciences, University of Sao Paulo, in accordance with the ethical principles of animal experimentation. The experiment was conducted in the Dairy Cattle Research Laboratory, Pirassununga, Brazil.

A total of 42 multiparous Holstein cows were randomly assigned to receive 1 of 4 diets during the preand postpartum periods: (1) control $(\mathbf{C O N} ; \mathrm{n}=11)$; (2) flaxseed (WF, n-3 FA source; $\mathrm{n}=11$ ), cows fed 60 $\mathrm{g} / \mathrm{kg}$ (prepartum) and $80 \mathrm{~g} / \mathrm{kg}$ (postpartum) of $\mathrm{WF}$ (diet DM basis); (3) whole raw soybeans (WS, n-6 FA source; $\mathrm{n}=10$ ), cows fed $120 \mathrm{~g} / \mathrm{kg}$ (prepartum) and $160 \mathrm{~g} / \mathrm{kg}$ (postpartum) of WS (diet DM basis); and (4) calcium salts of unsaturated FA (CSFA; Megalac-E, Elanco-Eli Lilly and Company, Indianapolis, IN, n-6 rumen-protected FA source; $\mathrm{n}=10$ ), cows fed $24 \mathrm{~g} / \mathrm{kg}$ (prepartum) and $32 \mathrm{~g} / \mathrm{kg}$ (postpartum) of CSFA (diet DM basis). The experimental diets were supplied from $35 \mathrm{~d}$ before the expected calving until 84 DIM and were formulated according to NRC (2001; Table 1).

At the start of the experiment, the CON group was composed of cows with $3.5 \pm 0.5$ parturitions, $762 \pm$ $14.1 \mathrm{~kg}$ of BW, and $3.1 \pm 0.18 \mathrm{BCS}$; the WF group was composed of cows with $4.0 \pm 0.5$ parturitions, $782 \pm$ $27.1 \mathrm{~kg}$ of BW, and $3.25 \pm 0.20 \mathrm{BCS}$; the WS group was composed of cows with $4.0 \pm 1.5$ parturitions, 712 $\pm 22.5 \mathrm{~kg}$ of BW, and $3.05 \pm 0.15 \mathrm{BCS}$; and the CSFA group was composed of cows with $4.0 \pm 1.0$ parturitions, $734 \pm 21.7 \mathrm{~kg}$ of BW, and $3.1 \pm 0.15 \mathrm{BCS}$ (mean $\pm \mathrm{SD})$.

Throughout the experiment, cows were housed in individual pens $\left(17.5 \mathrm{~m}^{2}\right)$ containing forced ventilation, sand beds, and individual feeding troughs. Diets were fed daily at 0800 and $1300 \mathrm{~h}$ as a TMR. Amounts of feed offered and orts for each cow were weighted daily and restricted to 5 to $10 \%$ of intake on an as-fed basis. Cows were mechanically milked daily at 0630 and $1530 \mathrm{~h}$, and milk yield measurements were made with an automatic milk meter that sent information to herd management software (Alpro, DeLaval, Tumba, Sweden).

\section{Analysis of FA}

The corn silage and Tifton hay were sampled weekly (17 samples), and ingredients of grain mixture (WF, WS, CSFA, ground corn, and soybean meal) were collected during the preparation of concentrate (4 samples) for chemical analysis. To analyze the FA in ingredients, lipids extraction and methylation were performed as described by Sukhija and Palmquist (1988) with minor modifications as described below. Extraction was done with $6 \mathrm{~mL}$ of chloroform, instead of 2 $\mathrm{mL}$, and methylations were done with methanolic- $\mathrm{HCl}$ but using a concentration of $6.5 \%$, instead of $10 \%$, and a volume of $9 \mathrm{~mL}$, rather than $3 \mathrm{~mL}$. Thus, the ratio of extracting solvent to methylation reagent was the same as in Sukhija and Palmquist (1988). Incubation time was increased from 2 to $2.5 \mathrm{~h}$, and temperature was reduced from 80 to $65^{\circ} \mathrm{C}$. Tubes were continuously checked for leaks during incubation and were repeated if substantial leaks occurred.

Fatty acids were quantified by gas chromatography (GC Shimadzu 2010 with automatic injection, Shimadzu Corporation, Kyoto, Japan) equipped with a SP-2560 capillary column $(100 \mathrm{~m} \times 0.25 \mathrm{~mm}$ i.d. with $0.02-\mu \mathrm{m}$ film thickness; Supelco, Bellefonte, PA). Oven temperature was $70^{\circ} \mathrm{C}$ for $4 \mathrm{~min}$, increased by $13^{\circ} \mathrm{C} / \mathrm{min}$ until $175^{\circ} \mathrm{C}$, and then held at this temperature for $27 \mathrm{~min}$. Finally, temperature was increased by $4^{\circ} \mathrm{C} / \mathrm{min}$ until it reached $215^{\circ} \mathrm{C}$ and then was kept at this temperature for 31 min. Hydrogen $\left(\mathrm{H}_{2}\right)$ was used as the carrier gas with a flow rate of $40 \mathrm{~cm}^{3} / \mathrm{s}$. Four standards were used for FA identification: standard C4-C24 (TM 37, Supelco Sigma-Aldrich Group), C18:1 trans-11 (V038-1G, Supelco Sigma-Aldrich Group), C18:2 trans-10, cis-12 (UC-61M 100 mg, Nu-Chek Prep Inc., Elysian, MN), and C18:2 cis-9, trans-11 (UC-60M $100 \mathrm{mg}$, Nu-Chek Prep Inc.).

\section{DMI and Energy Balance}

Orts samples ( $12.5 \%$ of total daily orts) were collected daily from each cow and were combined into a single sample for posterior chemical analysis. Samples were stored at $-20^{\circ} \mathrm{C}$. Dry matter (method 950.15), ether extract (method 920.39), and $\mathrm{CP}(\mathrm{N} \times 6.25$; 
method 984.13) were analyzed in the diet ingredients and orts according to the methods described by AOAC International (2000). The NDF and ADF content were obtained according to the method described by Van Soest et al. (1991). The NDF analysis was performed using $\alpha$-amylase (TE-149 fiber analyzer, Tecnal Equipaments Laboratório Inc., Piracicaba, Brazil). Total digestible nutrient and $\mathrm{NE}_{\mathrm{L}}$ were estimated according to NRC (2001).

Energy balance was calculated according to NRC (2001). Body weights were measured weekly, using a livestock scale (Brete Me2.80, Coimma, Dracena, Brazil) for large animals, after the morning milking (lactat- ing cows) and before the morning feeding (dry cows). Body condition score of cows was determined using a 0 to 5 scale in 0.25 increments similar to Wildman et al. (1982).

\section{Plasma Metabolites}

Blood samples were collected weekly throughout the trial period ( -35 d before the expected calving to 84 DIM) from coccygeal vessel puncture before the morning feeding. Blood samples were also collected during the first $24 \mathrm{~h}$ after parturition. Samples were collected in $10-\mathrm{mL}$ vacuum tubes for glucose, nonesterified FA

Table 1. Ingredients, nutrients, and fatty acid profile of experimental diets ${ }^{1}$

\begin{tabular}{|c|c|c|c|c|c|c|c|c|}
\hline Item & \multicolumn{4}{|c|}{ Prepartum } & \multicolumn{4}{|c|}{ Postpartum } \\
\hline Tifton hay & - & - & - & - & 5.04 & 5.06 & 5.02 & 5.03 \\
\hline Corn meal & 17.90 & 13.99 & 14.72 & 14.97 & 28.88 & 24.00 & 24.41 & 25.90 \\
\hline Soybean meal & 9.13 & 6.71 & - & 9.65 & 22.09 & 18.90 & 9.98 & 22.89 \\
\hline Whole raw soybean & - & - & 11.97 & - & - & - & 16.01 & - \\
\hline Urea & 0.97 & 0.97 & 0.97 & 0.97 & 0.35 & 0.35 & 0.35 & 0.35 \\
\hline Ammonium sulfate & 0.13 & 0.13 & 0.13 & 0.13 & 0.07 & 0.07 & 0.07 & 0.07 \\
\hline Sodium bicarbonate & - & - & - & - & 1.04 & 1.04 & 1.04 & 1.04 \\
\hline Magnesium oxide & - & - & - & - & 0.17 & 0.17 & 0.17 & 0.17 \\
\hline Phosphate & 0.08 & 0.08 & 0.08 & - & 0.68 & 0.68 & 0.68 & 0.68 \\
\hline Limestone & 0.41 & 0.41 & 0.41 & - & 1.00 & 1.00 & 1.00 & - \\
\hline $\mathrm{OM}$ & 93.06 & 93.07 & 93.14 & 92.98 & 91.52 & 91.54 & 91.61 & 91.85 \\
\hline $\mathrm{CP}$ & 13.23 & 13.10 & 12.99 & 13.35 & 17.47 & 17.26 & 17.23 & 17.61 \\
\hline Ether extract & 2.88 & 4.83 & 4.53 & 4.93 & 2.48 & 5.33 & 5.60 & 5.41 \\
\hline $\mathrm{NFC}$ & 38.19 & 35.79 & 36.17 & 36.08 & 42.39 & 38.99 & 38.65 & 39.80 \\
\hline NDF & 38.76 & 39.35 & 39.45 & 38.62 & 29.19 & 29.96 & 30.13 & 29.04 \\
\hline $\mathrm{ADF}$ & 20.34 & 20.49 & 20.52 & 20.29 & 15.08 & 15.28 & 15.38 & 15.03 \\
\hline Lignin & 4.78 & 4.81 & 4.09 & 4.05 & 3.76 & 3.80 & 3.70 & 3.71 \\
\hline Ash & 6.94 & 6.93 & 6.86 & 7.02 & 8.48 & 8.46 & 8.39 & 8.15 \\
\hline Total digestible nutrient & 68.06 & 70.30 & 70.54 & 70.55 & 70.02 & 73.13 & 73.35 & 73.81 \\
\hline $\mathrm{NE}_{\mathrm{L}}^{4}(\mathrm{Mcal} / \mathrm{kg}$ of DM$)$ & 1.55 & 1.72 & 1.71 & 1.70 & 1.71 & 1.89 & 1.88 & 1.89 \\
\hline \multicolumn{9}{|l|}{ Fatty acids $(\mathrm{g} / 100 \mathrm{~g}$ of $\mathrm{FA})$} \\
\hline C14:0 & 0.83 & 0.47 & 0.39 & 0.70 & 0.58 & 0.46 & 0.33 & 0.49 \\
\hline C16:0 & 30.74 & 11.42 & 13.24 & 25.31 & 25.97 & 11.30 & 12.78 & 21.39 \\
\hline C18:0 & 5.81 & 2.97 & 3.35 & 4.79 & 5.29 & 3.20 & 3.34 & 4.37 \\
\hline
\end{tabular}

${ }^{1} \mathrm{CON}=$ control, $\mathrm{WF}=$ whole flaxseed $(\mathrm{n}-3 \mathrm{FA}$ source $), \mathrm{WS}=$ whole raw soybean $(\mathrm{n}-6 \mathrm{FA}$ source), and CSFA = calcium salts of fatty acids (n-6 FA source).

${ }^{2}$ Content per kilogram: Mg, 10 g; S, 9 g; Zn, 23.75 mg; Cu, 5,625 mg; Mn, 18,125 mg; Fe, 5,000 mg; Co, 125 mg; I, 312 mg; Se, 144 mg; F, 900 mg; vitamin A; 2,000 IU; vitamin E, 12,500 mg; vitamin D, 5,000 IU.

${ }^{3}$ Vitamin premix (per kg): vitamin A, 8,000 IU; vitamin E, 50,000 mg; vitamin D, 2,300 IU.

${ }^{4}$ Calculated according to Weiss et al. (1992) and NRC (2001) equations, discounting indigestible CP of feed values for level of DMI and using one as processing factor. 
(NEFA), and BHB concentrations. After clot formation, samples were centrifuged at 2,000 $\times g$ for $15 \mathrm{~min}$ at $4^{\circ} \mathrm{C}$, and serum was transferred to plastic tubes and stored at $-20^{\circ} \mathrm{C}$ until analysis. The analyses of NEFA and BHB were performed using commercial kits (Randox FA115 and Ranbut RB100, Crumlin, UK) using an enzymatic colorimetric endpoint method that was evaluated on a microplate reader (Asys Brand, Model UV-Plus Expert, Biochrom, Cambridge, UK). Glucose analyses were performed using a commercial kit (CELM, Sao Caetano do Sul, Brazil) using a colorimetric endpoint method and read with an automatic biochemistry analyzer (SBA-200 automatic biochemistry, CELM).

\section{Flow Cytometer Phenotype, Phagocytosis and Adhesion Molecules Expression}

Whole blood samples were collected weekly (days $-35 \pm 2,-28 \pm 2,-21 \pm 2,-14 \pm 2,0,7 \pm 2$, $14 \pm 2,21 \pm 2$, and $28 \pm 2$ ) from cows before the morning feeding by puncture of coccygeal vessels into sterile vacutainers containing $10 \mathrm{~mL}$ of anticoagulant solution (heparin). The percentages of peripheral blood mononuclear cells and neutrophils were determined by flow cytometry (BD Accuri C6 cytometer and BD CFlow Plus software; BD Accuri, Ann Arbor, MI). Cell populations were identified using forward angle and side scatter gates as previously described by Hart et al. (2011). Fluorescently labeled antibodies were used to distinguish cell surface properties (Brown and Witter, 2000). Green fluorescent signal was analyzed independently for the monocyte and polymorphonuclear (PMN) cell populations. To calculate the percentage of cells bearing each marker, the entire percentage of positive cells for each antibody was determined, and the percentage positive cells for detection antibody for that animal was subtracted. The data are reported as percentages of positive cells for each marker. The phagocytic capacities of leukocytes, monocytes and macrophages, and neutrophils were evaluated according to the pHrodo method (a $\mathrm{pH}$-sensitive dye used to detect engulfment of apoptotic cells; Miksa et al., 2009). To measure phagocytic activity, PMN-enriched leukocytes and mononuclear cells were incubated with Staphylococcus aureus (Molecular Probes, Invitrogen, Carlsbad, CA). Incubations were performed for $30 \mathrm{~min}$ at $37^{\circ} \mathrm{C}$ in the dark, and then assay tubes were fixed at $4^{\circ} \mathrm{C}$ with $300 \mathrm{~mL}$ of $2 \%$ paraformaldehyde and held overnight at $4^{\circ} \mathrm{C}$ before analysis. Phagocytosis of internalized bacteria (measured in the presence of $0.04 \%$ Trypan Blue, Sigma-Aldrich, Buchs, Switzerland) was quantified (using a C6 flow cytometer, BD Accuri) in a population of leukocytes decreasing in size (forward scatter) and granularity (side scatter) within the gates containing PMN or monocytes. Percentage fluorescence was measured using BD Accuri C6-CFlow Plus Software according to techniques described by Hart et al. (2011) and Wiggins et al. (2011). The percentage of PMN leukocytes that phagocytized the bacteria and the median fluorescence intensity of phagocytosis were calculated as described in Blagitz et al. (2013).

Blood samples were transported to the laboratory at room temperature and centrifuged at $1,500 \times g$ for $30 \mathrm{~min}$ at $4^{\circ} \mathrm{C}$. The buffy coat was transferred to a $50-$ $\mathrm{mL}$ conical tube (Oliveira and Hansen, 2008). Platelets were lysed with $30 \mathrm{~mL}$ of lysis solution containing 0.37 $\mathrm{g}$ of disodium EDTA, $0.80 \mathrm{~g}$ of ammonium chloride, and $0.84 \mathrm{~g}$ of sodium bicarbonate. Another $15 \mathrm{~mL}$ of Dulbecco's phosphate buffer solution was then added into the tubes and centrifuged at 1,600 $\times g$ for $15 \mathrm{~min}$ at $4^{\circ} \mathrm{C}$. The cell pellets were collected, and the cellular viability and concentration were determined by Trypan Blue exclusion using a hemocytometer adjusted for 1 $\times 10^{6}$ cells $/ \mathrm{mL}$. Specific flow cytometry protocols for cell membrane marker protein staining were assayed. Briefly, $5 \times 10^{6}$ cells were pipetted in polyethylene tubes of $13 \times 100 \mathrm{~mm}$, rinsed twice with fluorescenceactivated cell sorting tampon (PBS with $1 \%$ of fetal bovine serum), and then resuspended in a smaller volume. The cells were incubated with primary antibody for $30 \mathrm{~min}$ at room temperature, to analyze T-helper cells $\left(\mathrm{CD} 4^{+}\right)$, T-cytotoxic cells $\left(\mathrm{CD}^{+}\right)$, T-regulatory cells $\left(\mathrm{CD} 25^{+}\right)$, monocytes, and macrophages for adhesion molecule $\left(\mathrm{CD} 14^{+}\right)$and T-cell memory marker of neutrophils $\left(\mathrm{CD} 2 \mathrm{~L}^{+}\right)$. Cells were rinsed once with 1 $\mathrm{mL}$ of fluorescence-activated cell sorting tampon to remove excess antibodies.

Based on closest day of blood collection, analyses were grouped into the following days: $-28,-21,-7$ d prepartum, until $24 \mathrm{~h}$ postpartum, or $7,14,21,28$, 56 , and $84 \mathrm{~d}$ postpartum. To quantify cellular adhesion molecule expression and phagocytosis intensity, blood samples were grouped into days $-28,-21,-7$ prepartum, until $24 \mathrm{~h}$ postpartum, and 7, 14, 21, and $28 \mathrm{~d}$ postpartum.

\section{Statistical Analysis}

The data were subjected to SAS (version 9.1.3, 2004, SAS Institute Inc., Cary, NC), verifying the normality of residuals and homogeneity of variances by PROC UNIVARIATE. Data were analyzed by PROC MIXED according to the following model of time repeated measures (Littell et al., 2006):

$$
Y_{i j k}=\mu+D_{i}+T_{j}+D_{i} \times T_{j}+a_{k}+e_{i j k},
$$


where $Y_{i j k}=$ dependent variable; $\mu=$ overall mean; $D_{i}$ $=$ fixed effect of diet; $T_{j}=$ random effect of time; $D_{i} \times$ $T_{j}=$ interaction between diet and time; $a_{k}=$ random effect of animal; and $e_{i j k}=$ residual error. Autoregressive method was used to calculate the covariance structure. The degrees of freedom were calculated according to the Satterthwaite's method $(\mathrm{ddfm}=$ satterth $)$. Autoregressive 1 was the best covariance structure based on the smallest Akaike's information criterion values. Other covariance structures were tested including compound symmetry, heterogeneous compound symmetry, unstructured and heterogeneous autoregressive 1. In addition, the data from the first sampling date of blood parameters were added as a covariate in the statistical analysis. Orthogonal contrasts were $\mathbf{C 1}$ (CON vs. WF + WS + CSFA), C2 (WF vs. WS + CSFA), and C3 (WS vs. CSFA). Statistical significance was defined as $P<0.05$.

\section{RESULTS}

\section{Diet and Ingredients Composition}

Similar CP and NDF contents were observed among diets during the pre- and postpartum period. As expected, when supplemental fat was added, ether extract and $\mathrm{NE}_{\mathrm{L}}$ contents were increased and NFC content decreased (Table 1). The NDF and ADF were similar among the diets.

As designed, the proportions of FA were quite different among the diets. The C18:2 (n-6) FA was much greater in the WS and CSFA diets than the CON or WF diets, with slightly more C18:2 FA in the WS than the CSFA diet during the prepartum $(8.35 \mathrm{~g} / 100 \mathrm{~g}$ of FA) and postpartum (3.83 g/100 g of FA) periods. For C18:3 FA (n-3), the WF diet had much greater C18:3 FA than the other diets during the prepartum (37.91 $\mathrm{g} / 100 \mathrm{~g}$ of FA vs. CON, WS, and CSFA with 2.52, 4.35, and $1.92 \mathrm{~g} / 100 \mathrm{~g}$ of $\mathrm{FA}$, respectively) or postpartum $(36.92 \mathrm{~g} / 100 \mathrm{~g}$ of FA vs. CON, WS, and CSFA with $4.98,5.25$, and $4.04 \mathrm{~g} / 100 \mathrm{~g}$ of $\mathrm{FA}$, respectively) periods.

\section{DMI, Milk Yield, and Plasma Metabolites}

Diets containing supplemental n-6 FA (WS and CSFA) decreased DMI compared with n-3 FA (WF; $P$ $<0.03)$ during the prepartum period but not during the postpartum period $(P=0.339)$. However, BCS was not altered by diet or fat source during the pre- or postpartum periods. Energy balance was not affected by diets during the prepartum period $(P=0.246)$ but was affected by diet in the postpartum period $(P=$ 0.001) with increased $(P=0.046)$ energy balance when fat sources were added to the diet postpartum $(-5.2$ vs. $-1.27 \mathrm{Mcal} / \mathrm{d}$ for cows fed CON vs. fat-supplemented diets, respectively). Plasma glucose concentrations were greater for cows fed WF than cows fed WS and CSFA during prepartum $(P=0.043)$ and postpartum $(P=$ 0.041) periods (Table 2).

Diets containing n-3 FA (WF) decrease plasma concentration of BHB compared with n-6 FA (WS and CSFA; $P=0.004$ ) during the postpartum period but did not alter plasma concentrations of NEFA. An effect of time was observed for almost all variables in both the pre- and postpartum periods (Figures 1 and 2).

\section{Effect of Supplemental Fat on Phagocytosis and Phagocytosis Intensity}

Diet and time had a dramatic effect on percentage of circulating leukocytes, monocytes, or neutrophils that were positive for phagocytosis either during the pre- or postpartum periods (Table 3). For circulating leukocytes, supplementation of fat increased phagocytosispositive leukocytes by $55.4 \%$ during the prepartum period $(P=0.006 ; 21.3$ vs $33.1 \%$; calculated as 33.1 $-21.3=11.8,11.8 / 21.3=55.4 \%)$ and $25.3 \%$ during the postpartum period ( $P=0.045 ; 26.1$ vs $32.7 \%$ ). Phagocytosis-positive leukocytes were greater for WF than WS or CSFA (Table 3) in both the prepartum $(P$ $=0.005)$ and postpartum $(P=0.001)$ periods. The 2 sources of n-6 FA were not different from each other either during the prepartum or postpartum periods (Table 3).

For phagocytosis-positive monocytes, there was a dramatic increase due to fat supplementation during the prepartum period $(77.6 \% ; P=0.001)$ and a less dramatic $(19.7 \% ; P=0.013)$ increase during the postpartum period. During the prepartum period WF produced a greater $(P=0.004)$ increase in phagocytosispositive monocytes than the diets supplemented with n-6 FA (WS and CSFA), but this was not the case in the postpartum period $(P=0.123)$. For phagocytosispositive neutrophils, there were more subtle effects of diet in the prepartum $(P=0.05)$ and postpartum $(P$ $=0.046)$ periods. These effects were primarily due to greater phagocytosis-positive neutrophils in WF than other FA-supplemented diets in the prepartum $(P=$ 0.009 for $\mathrm{C} 2)$ and postpartum $(P=0.006)$ periods (Table 3).

For the intensity of phagocytosis per cell, there was an effect of diet on leukocytes (prepartum, $P=0.014$ ), monocytes (prepartum, $P=0.009$; postpartum, $P=$ 0.001 ), and neutrophils (postpartum, $P=0.009$ ). The prepartum effect of diet on phagocytosis intensity per 
Table 2. Dry matter intake, milk yield, and plasmatic metabolites of cows fed diets rich in n-3 or n-6 fatty acids (mean \pm SEM)

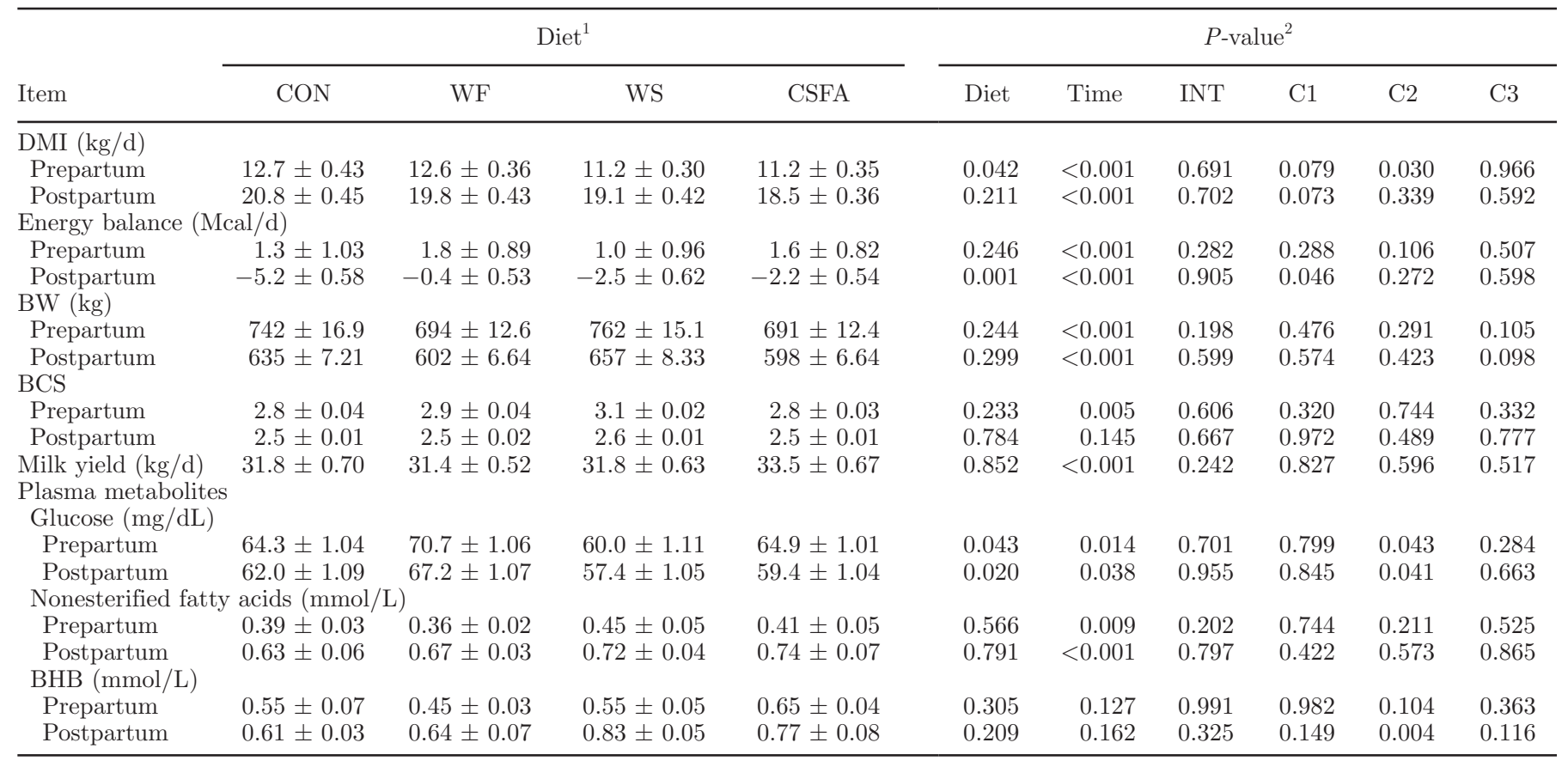

${ }^{1} \mathrm{CON}=$ control, $\mathrm{WF}=$ whole flaxseed $(\mathrm{n}-3 \mathrm{FA}$ source), WS $=$ whole raw soybean $(\mathrm{n}-6 \mathrm{FA}$ source), and CSFA $=$ calcium salts of fatty acids (n-6 FA source).

${ }^{2}$ Time (days), $\mathrm{INT}=$ diet $\times$ time, $\mathrm{C} 1=\mathrm{CON}$ vs. diets with supplemental fat, $\mathrm{C} 2=\mathrm{WF}$ vs. WS $+\mathrm{CSFA}$, and C3 = WS vs. CSFA.

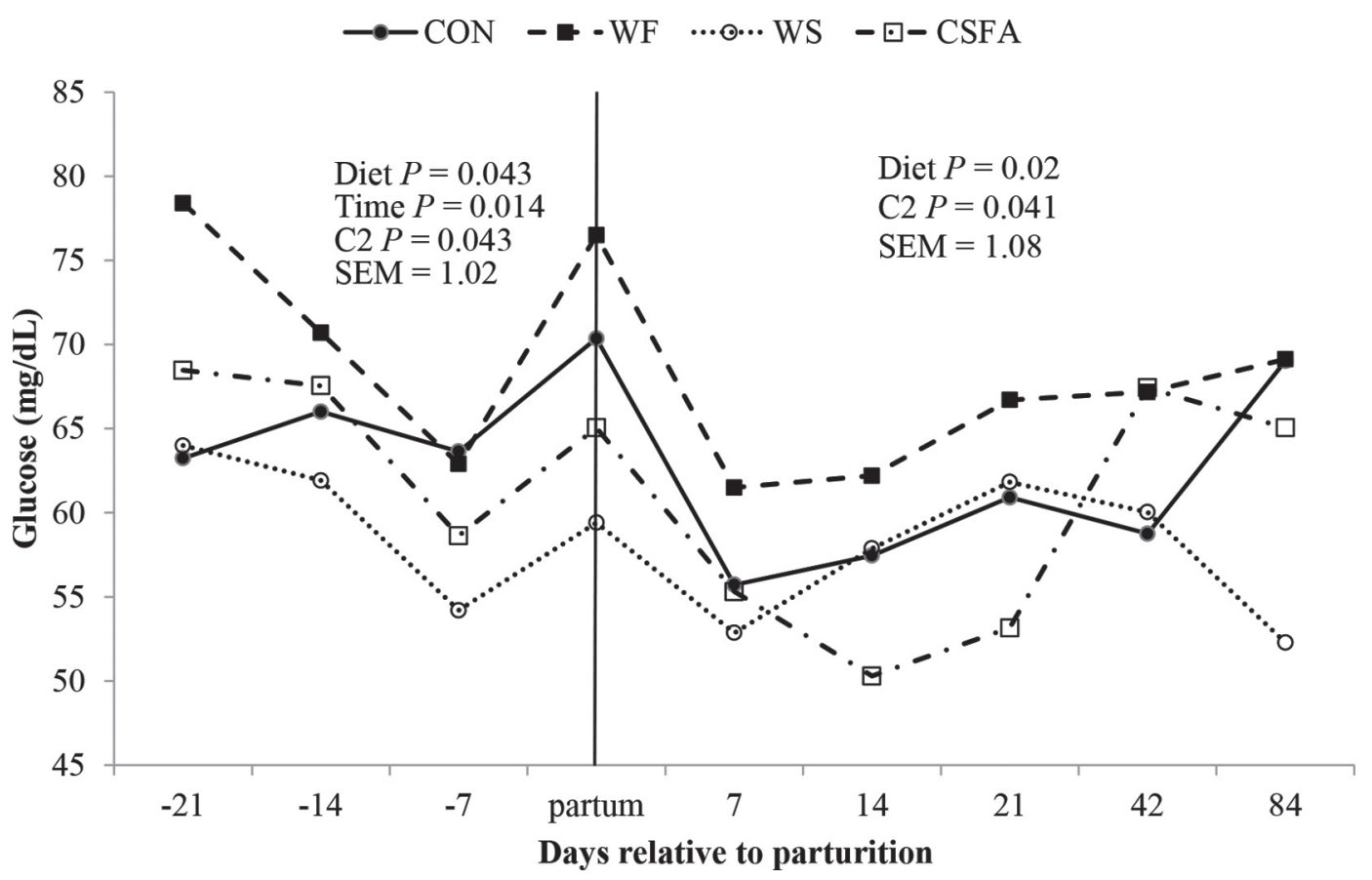

Figure 1. Glucose blood concentration of cows fed diets rich in n-3 or n-6 fatty acids: control (CON), whole flaxseed (WF, n-3 fatty acid source), whole raw soybean (WS, n-6 fatty acid source), and calcium salts of fatty acids (CSFA, n-6 fatty acid source). C2 = WF versus WS + CSFA. 


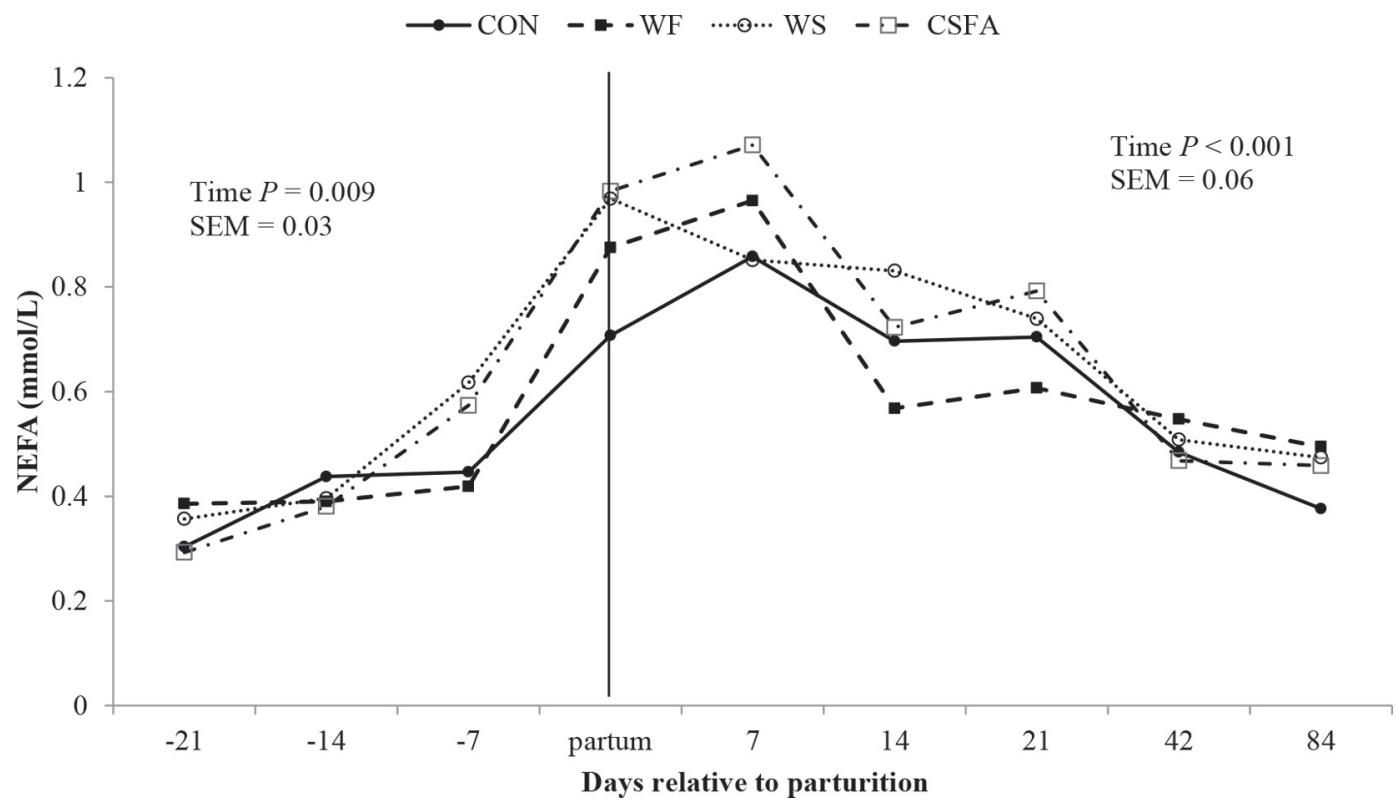

Figure 2. Nonesterified fatty acid (NEFA) blood concentration of cows fed diets rich in n-3 or n-6 fatty acids: control (CON), whole flaxseed (WF, n-3 fatty acid source), whole raw soybean (WS, n-6 fatty acid source), and calcium salts of fatty acids (CSFA, n-6 fatty acid source).

leukocyte was primarily related to the overall effect of FA supplementation $(P=0.001$ for $\mathrm{C} 1)$. In monocytes, the prepartum and postpartum dietary effects were related to overall effects of FA supplementation (C1) with greater intensity per monocyte in WF than in n-6 FA supplementation $(\mathrm{C} 2)$ during prepartum $(P=$ $0.011)$ and postpartum $(P=0.033)$ periods. The effect of postpartum diet on intensity per neutrophil was primarily related to the greater intensity in WF than other FA supplementation $(\mathrm{C} 2, P=0.04)$

Table 3. Percentage of positive cells for phagocytosis and phagocytosis intensity of cows fed diets rich in n-3 or n-6 fatty acids (mean \pm SEM)

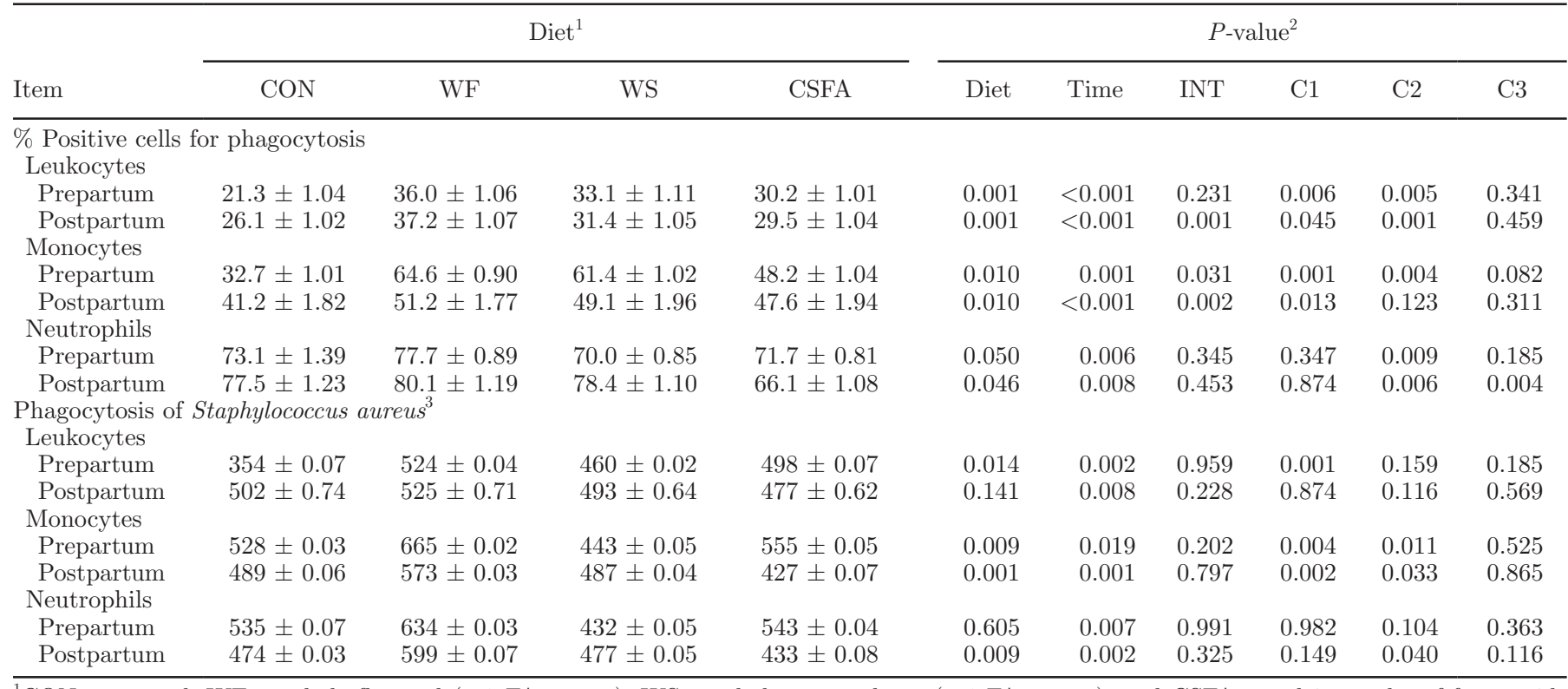

${ }^{1} \mathrm{CON}=$ control, $\mathrm{WF}=$ whole flaxseed $(\mathrm{n}-3 \mathrm{FA}$ source), WS $=$ whole raw soybean $(\mathrm{n}-6$ FA source), and CSFA $=$ calcium salts of fatty acids (n-6 FA source).

${ }^{2}$ Time (days), $\mathrm{INT}=$ diet $\times$ time, $\mathrm{C} 1=\mathrm{CON}$ vs. diets with supplemental fat, $\mathrm{C} 2=\mathrm{WF}$ vs. WS + CSFA, and C3 $=$ WS vs. CSFA.

${ }^{3}$ Median fluorescence intensity. 


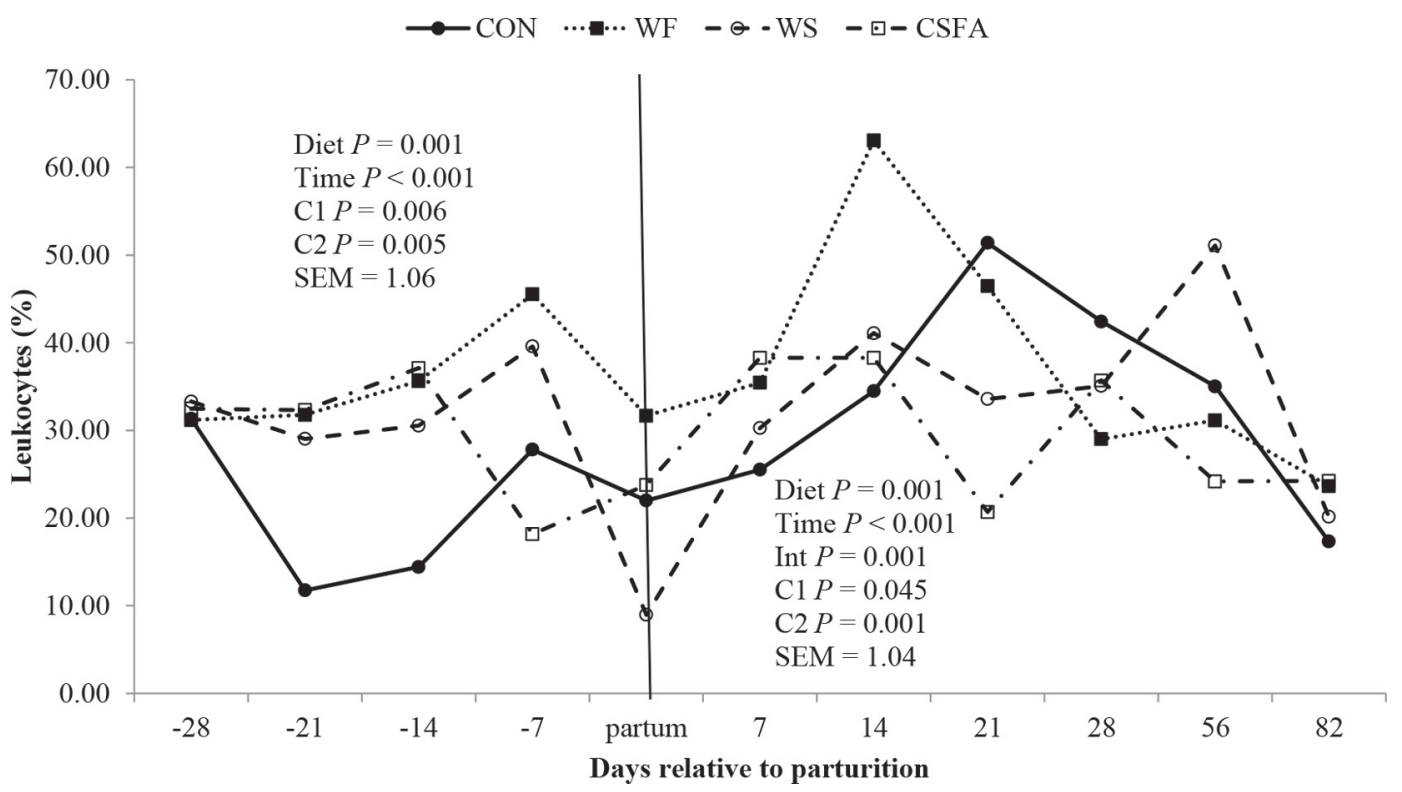

Figure 3. Leukocytes (\% of total leukocytes) positive for phagocytosis of cows fed diets rich in n-3 or n-6 fatty acids: control (CON), whole flaxseed (WF, n-3 fatty acid source), whole raw soybean (WS, n-6 fatty acid source), and calcium salts of fatty acids (CSFA, n-6 fatty acid source). Int $=$ diet $\times$ time; $\mathrm{C} 1=\mathrm{CON}$ versus diets with supplemental fat; $\mathrm{C} 2=\mathrm{WF}$ versus WS $+\mathrm{CSFA}$.

The time and diet effects as well as any interactions are illustrated for phagocytosis-positive leukocytes (Figure 3), monocytes (Figure 4), and neutrophils (Figure 5). For all of the immune cells, the percentage of cells that were positive for phagocytosis decreased near the time of parturition, relatively independent of diet. Interactions between time and diet were observed for leukocytes during the postpartum period $(P=0.001)$ and for monocytes during both the prepartum $(P=$ $0.031)$ and postpartum $(P=0.002)$ periods.

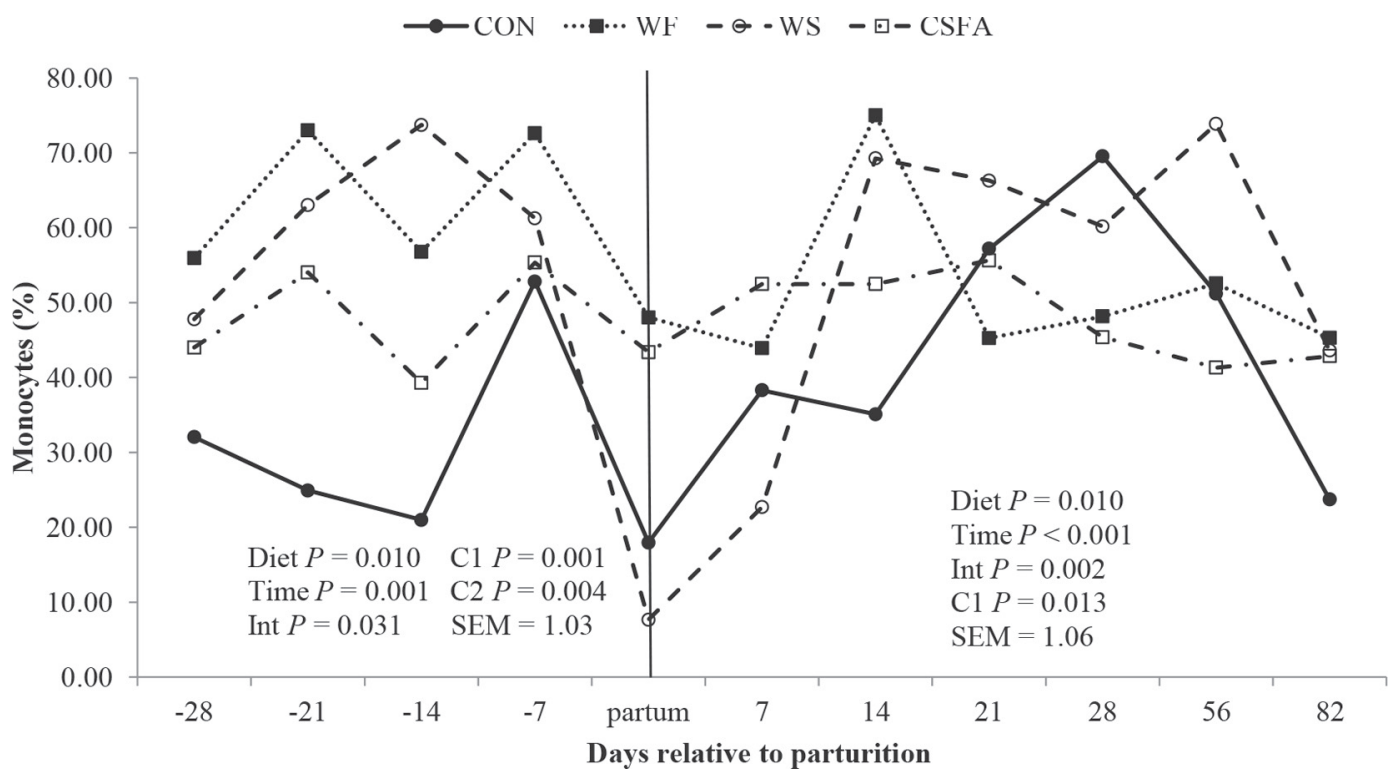

Figure 4. Monocytes (\% total monocytes) positive for phagocytosis of cows fed diets rich in n-3 or n- 6 fatty acids: control (CON), whole flaxseed (WF, n-3 fatty acid source), whole raw soybean (WS, n-6 fatty acid source), and calcium salts of fatty acids (CSFA, n-6 fatty acid source). Int $=$ diet $\times$ time; $\mathrm{C} 1=\mathrm{CON}$ versus diets with supplemental fat, $\mathrm{C} 2=\mathrm{WF}$ versus $\mathrm{WS}+\mathrm{CSFA}$. 


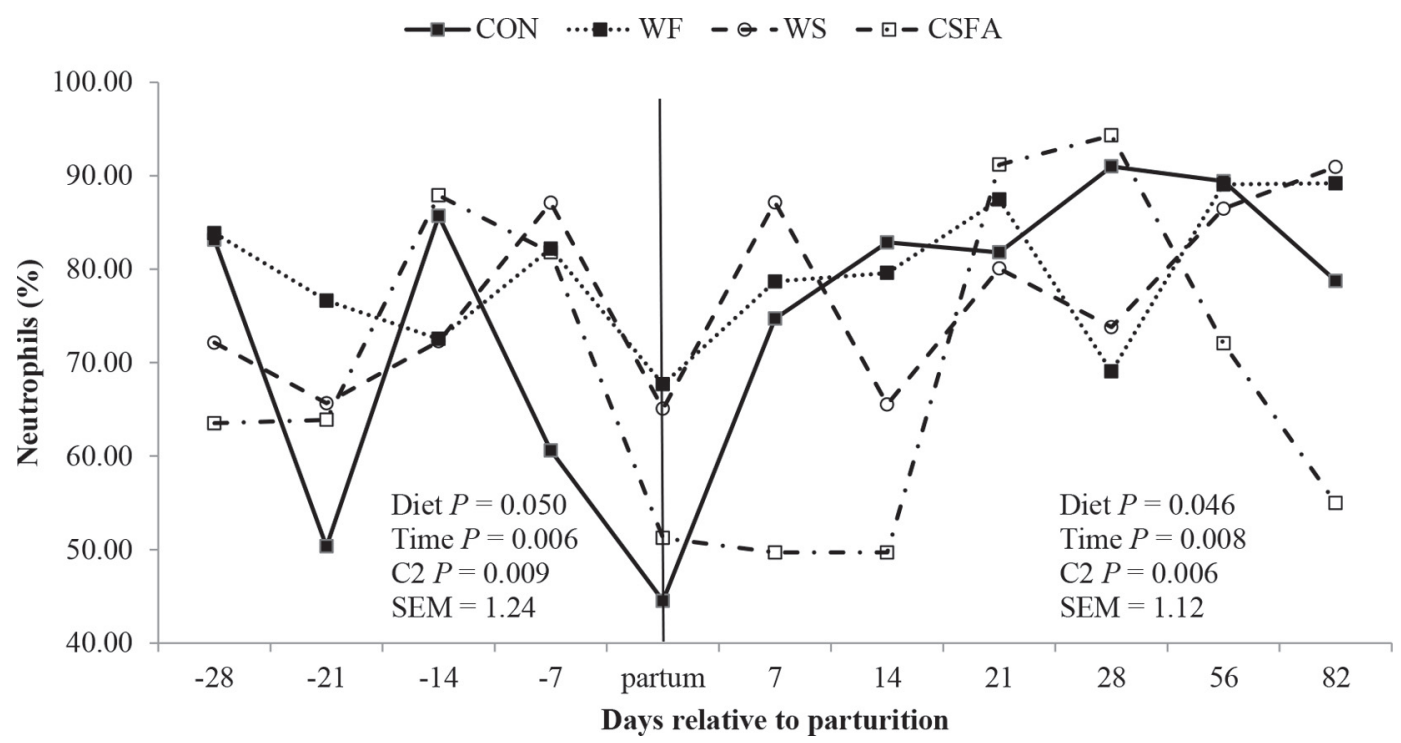

Figure 5. Neutrophils (\% of total neutrophils) positive for phagocytosis of cows fed diets rich in n-3 or n- 6 fatty acids: control (CON), whole flaxseed (WF, n-3 fatty acid source), whole raw soybean (WS, n-6 fatty acid source), and calcium salts of fatty acids (CSFA, n-6 fatty acid source). $\mathrm{C} 2=\mathrm{WF}$ versus WS + CSFA.

The effects of time on phagocytosis intensity of leukocytes, monocytes, and neutrophils demonstrated a decrease from 4 wk prepartum until the calving date and a progressive increase during the 4 wk postpartum (Figures 6-8).

\section{Adhesion Molecule Expression}

Supplemental FA increased percentage of cells with expression of $\mathrm{CD}^{+}$during the pre- and postpartum periods, and $\mathrm{CD} 8^{+}, \mathrm{CD} 25^{+}$, and $\mathrm{CD} 62 \mathrm{~L}^{+}$during the

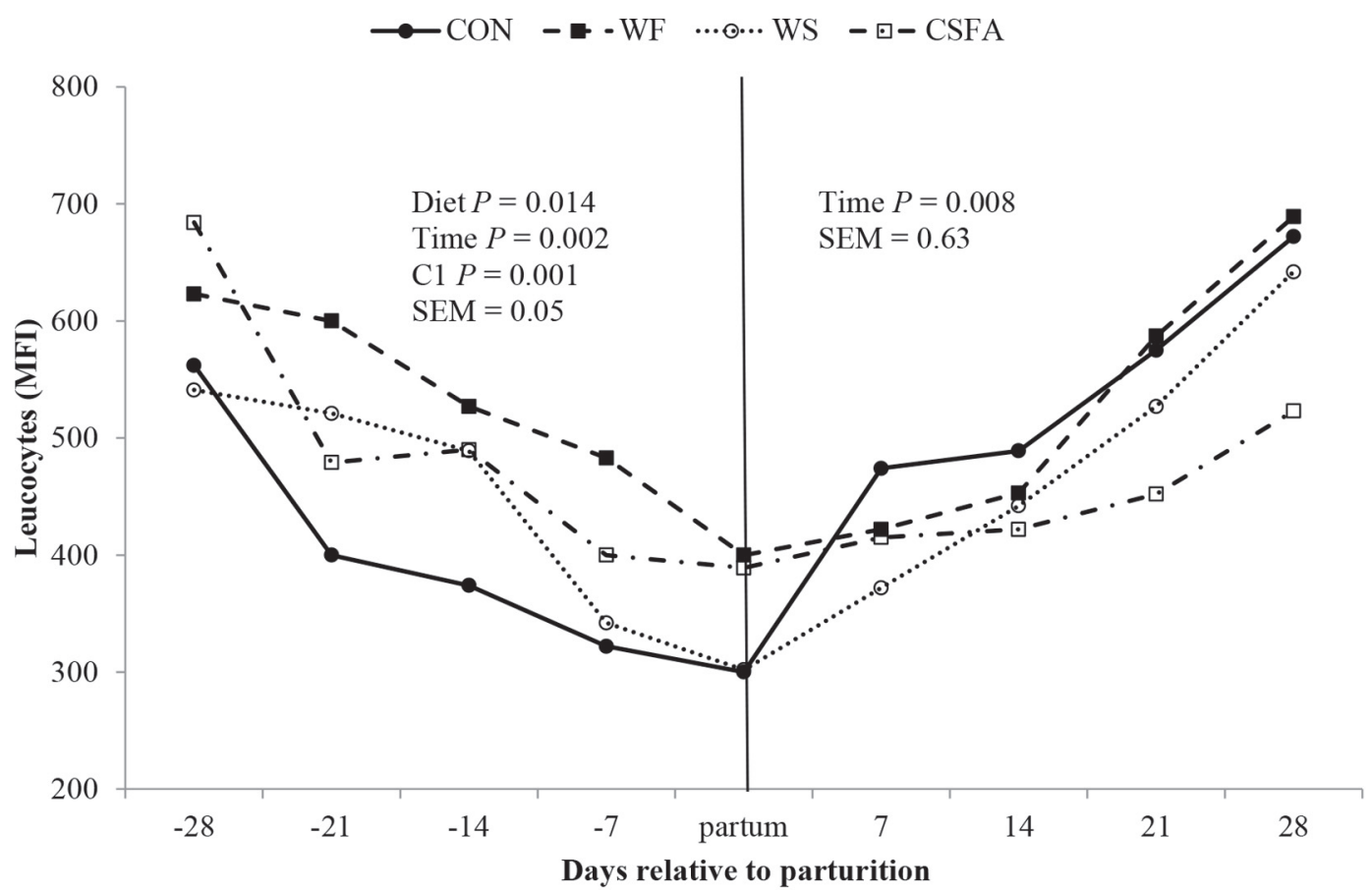

Figure 6. Median fluorescence intensity (MFI) of leukocytes phagocytosis of cows fed diets rich in n-3 or n-6 fatty acids: control (CON), whole flaxseed (WF, n-3 fatty acid source), whole raw soybean (WS, n-6 fatty acid source), and calcium salts of fatty acids (CSFA, n-6 fatty acid source). $\mathrm{C} 1=\mathrm{CON}$ versus diets with supplemental fat. 


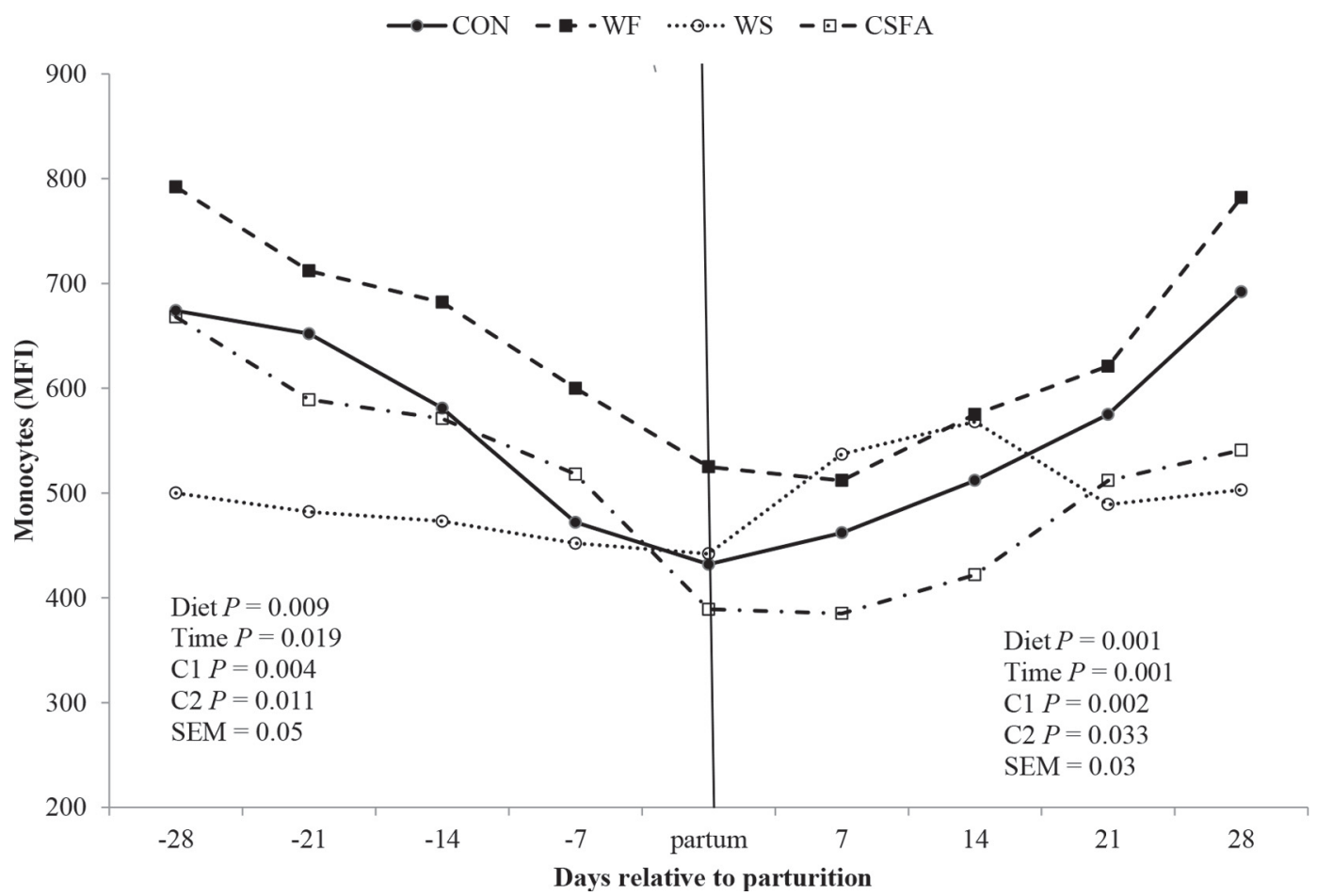

Figure 7. Median fluorescence intensity (MFI) of monocytes phagocytosis of cows fed diets rich in n-3 or n-6 fatty acids: control (CON), whole flaxseed (WF, n-3 fatty acid source), whole raw soybean (WS, n-6 fatty acid source), and calcium salts of fatty acids (CSFA, n-6 fatty acid source). $\mathrm{C} 1=\mathrm{CON}$ versus diets with supplemental fat; $\mathrm{C} 2=\mathrm{WF}$ versus WS + CSFA.

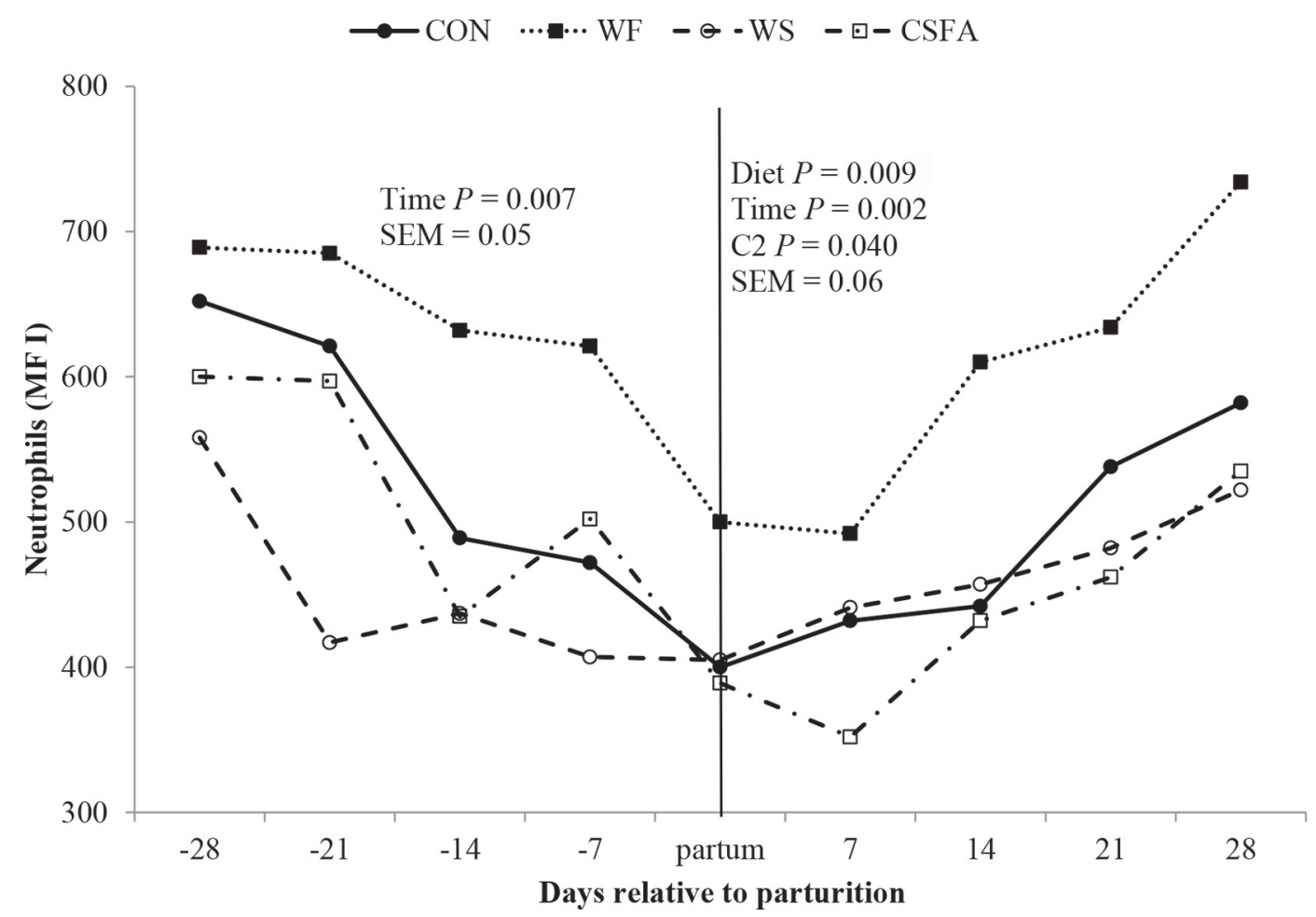

Figure 8. Median fluorescence intensity (MFI) of neutrophils phagocytosis of cows fed diets rich in n-3 or n-6 fatty acids: control (CON), whole flaxseed (WF, n-3 fatty acid source), whole raw soybean (WS, n-6 fatty acid source), and calcium salts of fatty acids (CSFA, n-6 fatty acid source). $\mathrm{C} 2=\mathrm{WF}$ versus $\mathrm{WS}+\mathrm{CSFA}$. 


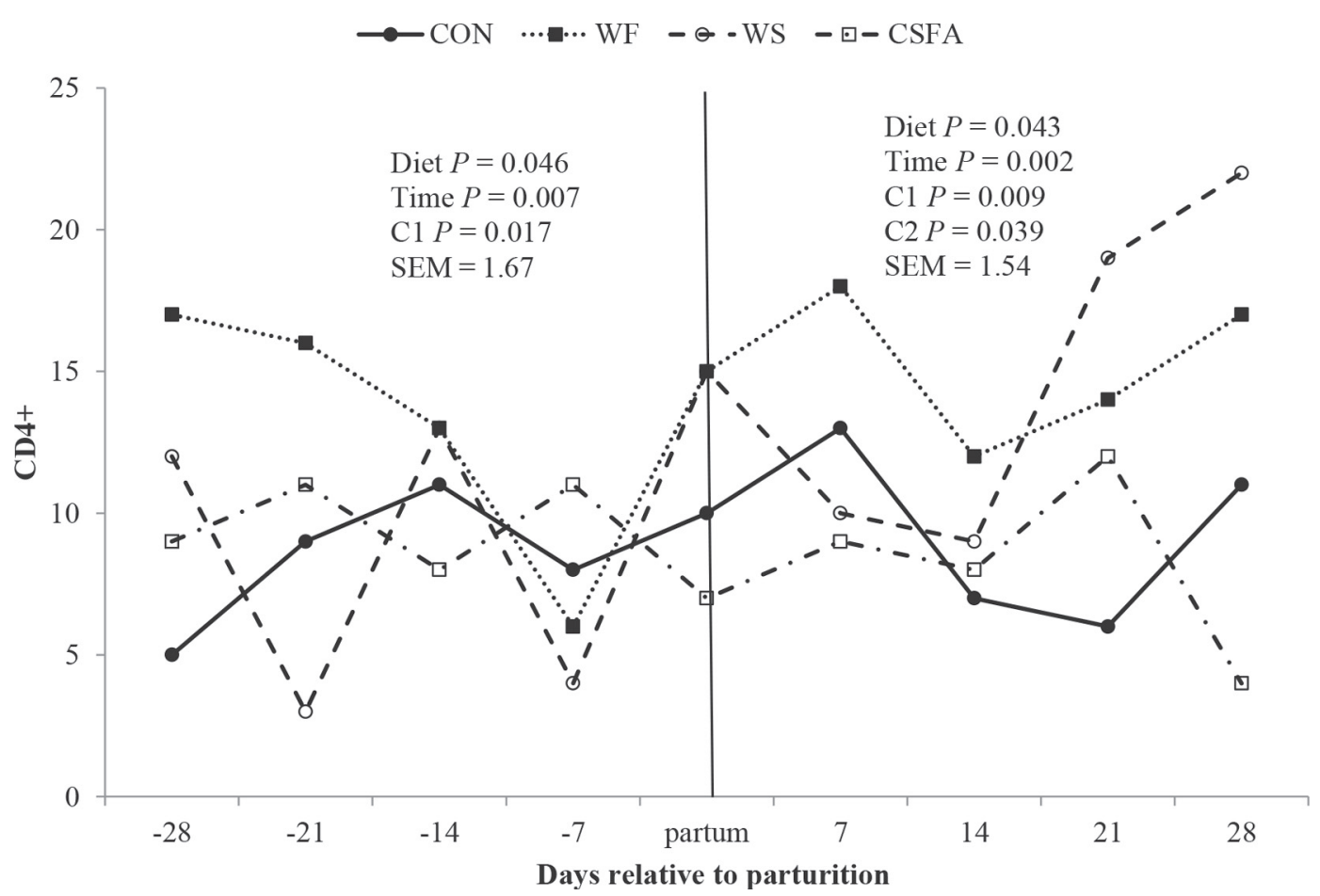

Figure 9. Percentage of cells expressing CD4 of cows fed diets rich in n-3 or n- 6 fatty acids: control (CON), whole flaxseed (WF, n-3 fatty acid source), whole raw soybean (WS, n-6 fatty acid source), and calcium salts of fatty acids (CSFA, n-6 fatty acid source). C1 = CON versus diets with supplemental fat; $22=\mathrm{WF}$ versus WS + CSFA.

postpartum period (Figures 9-12) during the postpartum period. Cows fed WF had greater expression of $\mathrm{CD}^{+}$(postpartum) than cows fed WS and CSFA. Cows fed WS and CSFA demonstrated greater expression of $\mathrm{CD}^{+} 4^{+}$(pre- and postpartum) compared with cows fed WF (Table 4). An effect of time was observed in expression of $\mathrm{CD} 4^{+}$and $\mathrm{CD} 62 \mathrm{~L}^{+}$, during prepartum, and an effect of time was observed in expression of $\mathrm{CD}^{+}, \mathrm{CD}^{+}$, and $\mathrm{CD} 2 \mathrm{~L}^{+}$during the postpartum period (Figures 9, 10, and 12). Almost all adhesion molecules maintained expression during pre- and postpartum periods, except for $\mathrm{CD}_{62 \mathrm{~L}^{+}}$expression, which increased expression after the first week postpartum in all diets (Figure 12).

\section{DISCUSSION}

Fat supplementation increases dietary energy density (Grummer et al., 2004), and if the DMI is not altered, the $\mathrm{NE}_{\mathrm{L}}$ intake would be greater and, consequently, could mitigate the negative energy balance of earlylactating cows. Greco et al. (2015) observed that reducing the ratio of n-6 to n-3 FA in the diet of dairy cows increased DMI. Dry matter intake of cows fed WF was greater than those fed WS or CSFA during the prepartum period, and this finding is likely to be related to the NDF digestibility coefficient (0.587 versus 0.537 for WF and WS+CSFA, respectively; data not shown). Fiber is retained in the rumen longer than other feed components, and changes in NDF digestion can influence the filling effect on stretch receptors in the muscle layer in the rumen wall, which stimulates brain satiety centers to signal the end of a meal (Allen, 2000).

Blood glucose concentrations were greater in cows fed WF than CSFA during the experimental periods. This result is likely related to the greater DMI during the prepartum period; however, why the glucose response persisted during the postpartum period is unclear. Evidence exists that diets rich in n-6 FA can induce insulin resistance (Lichtenstein and Schwab, 2000), and n-3 FA has been shown to prevent the insulin resistance that is produced by feeding high fat diets to mice (Storlien et al., 1987; Storlien et al., 1991).

The lower BHB blood concentrations in cows fed WF compared with WS and CSFA could be related to specific effects of linolenic FA on the liver. $\beta$-Hydroxybutyrate is increased due to partial oxidation of NEFA, which occurs when the uptake of NEFA exceeds the liver capacity to oxidize it into $\mathrm{CO}_{2}$ (Grummer, 2008). $\beta$-Hydroxybutyrate is released from the liver and used as an energy source by peripheral tissues. N-3 FA are regulators of lipid metabolism in the liver of rodents and humans, decreasing FA conversion to triglycerides and ketone bodies (BHB) and promoting 


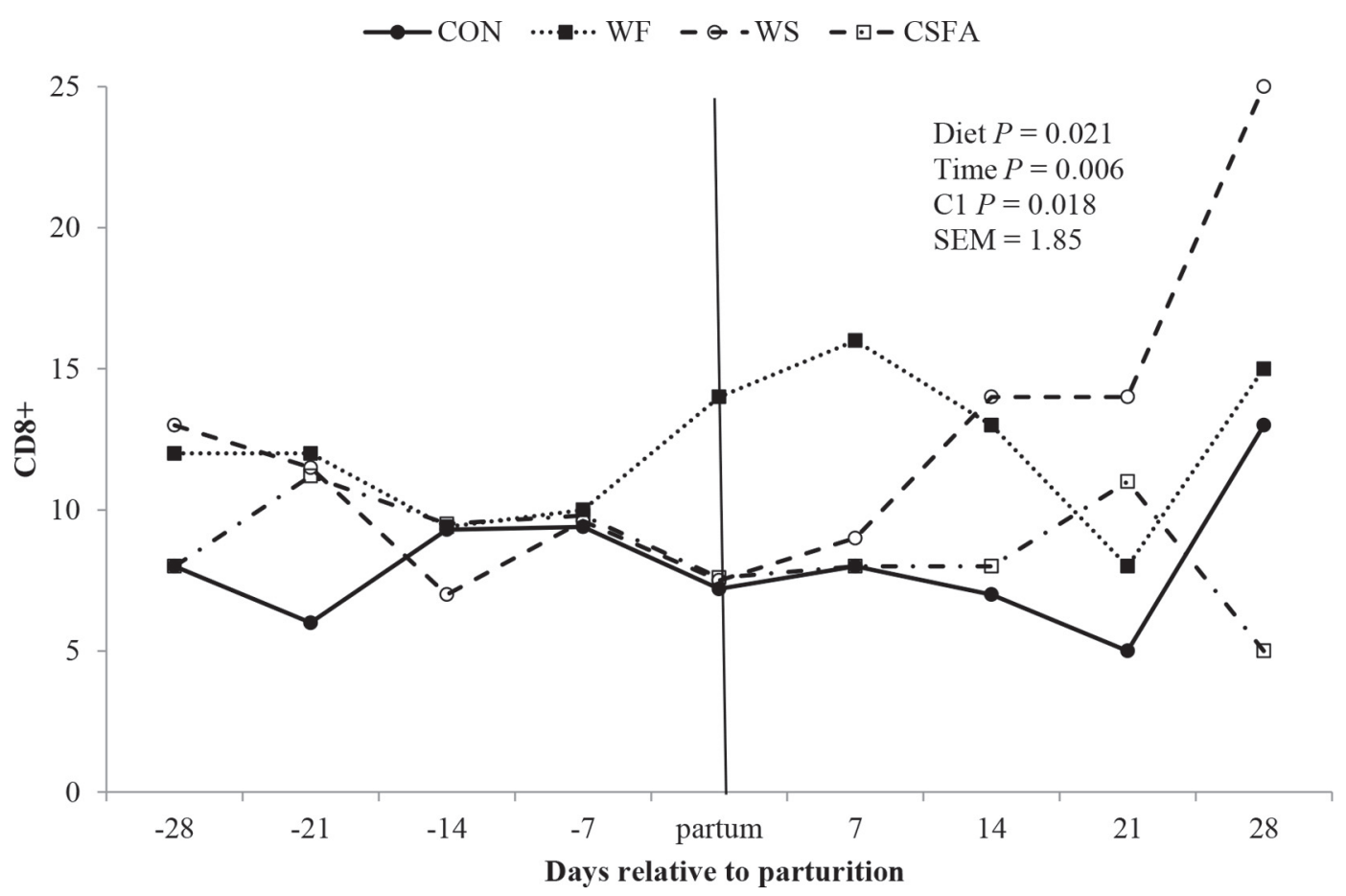

Figure 10. Percentage of cells expressing CD8 of cows fed diets rich in n-3 or n-6 fatty acids: control (CON), whole flaxseed (WF, n-3 fatty acid source), whole raw soybean (WS, n- 6 fatty acid source), and calcium salts of fatty acids (CSFA, n- 6 fatty acid source). C1 = CON versus diets with supplemental fat.

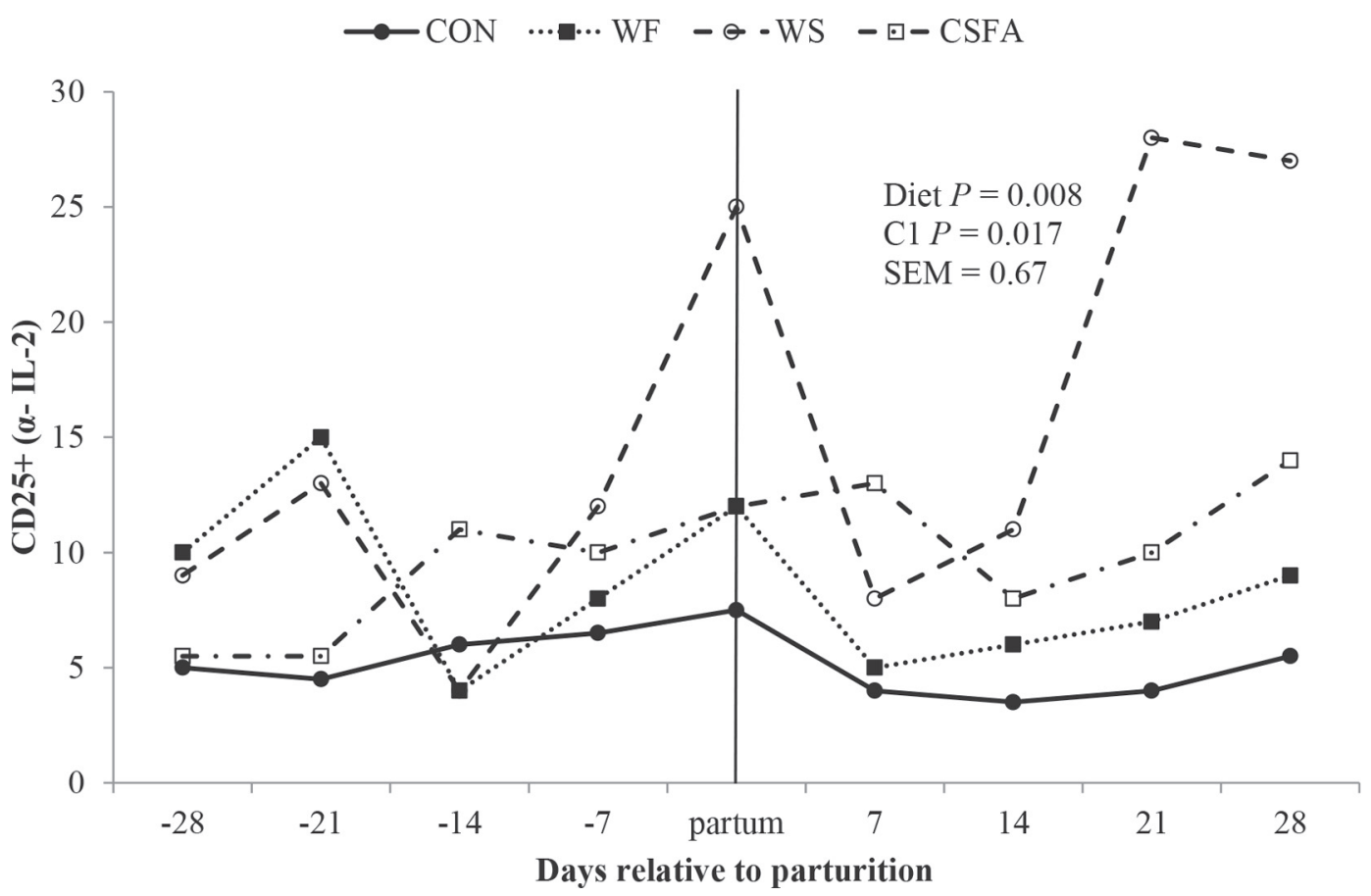

Figure 11. Percentage of cells expressing CD25 of cows fed diets rich in n-3 or n-6 fatty acids: control (CON), whole flaxseed (WF, n-3 fatty acid source), whole raw soybean (WS, n-6 fatty acid source), and calcium salts of fatty acids (CSFA, n- 6 fatty acid source). C1 = CON versus diets with supplemental fat. 


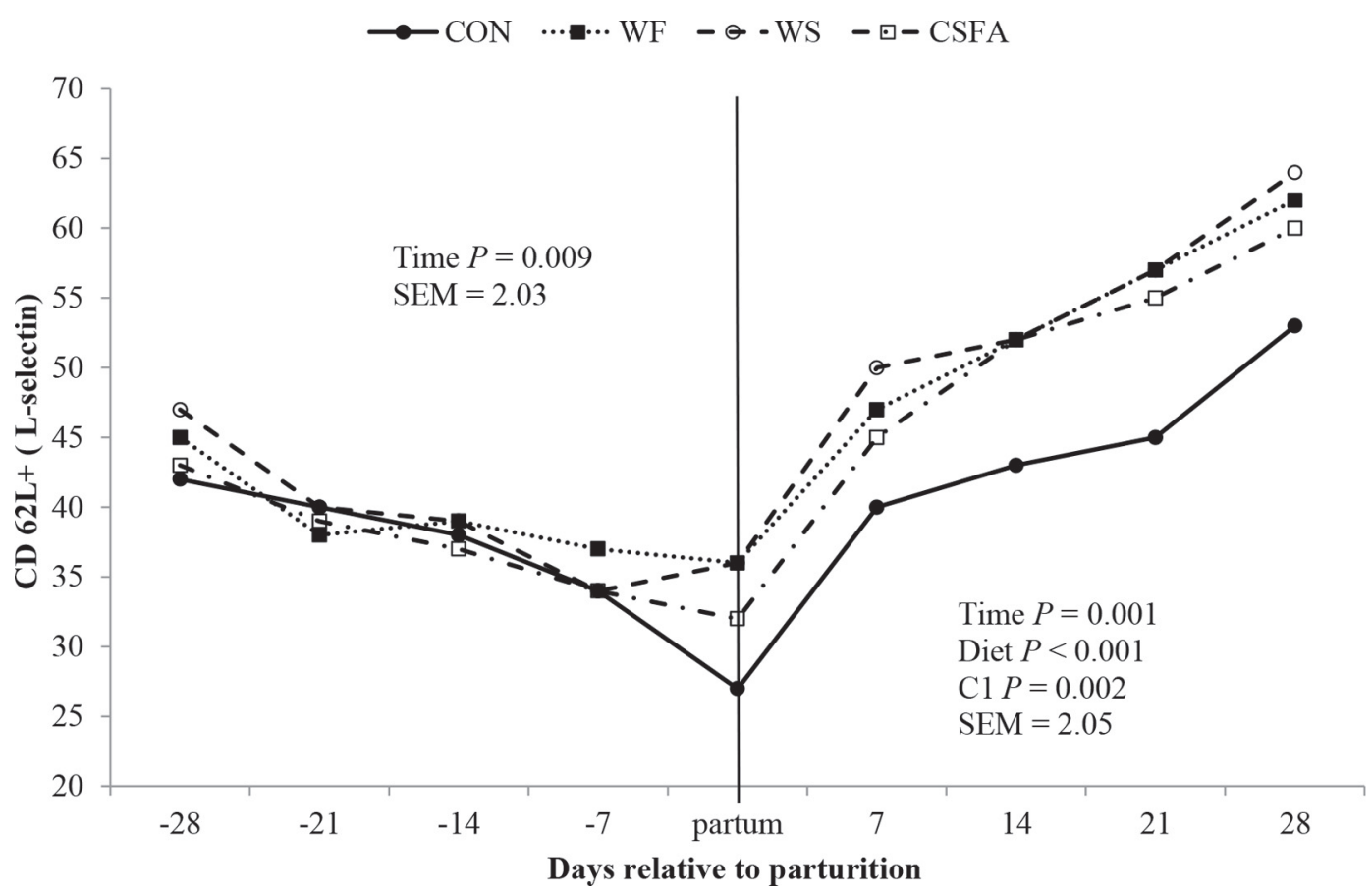

Figure 12. Percentage of cells expressing CD62L of cows fed diets rich in n-3 or n-6 fatty acids: control (CON), whole flaxseed (WF, n-3 fatty acid source), whole raw soybean (WS, n-6 fatty acid source), and calcium salts of fatty acids (CSFA, n-6 fatty acid source).

FA oxidation into $\mathrm{CO}_{2}$ (Grummer, 2008). Mashek et al. (2005) infused intravenously either emulsions of tallow, linseed oil, or fish oil in dry cows that were induced to have fatty liver. They observed that linseed oil reduced liver triacylglyceride accumulation.
The innate immune system is mediated primarily by leukocytes, such as monocytes and macrophages, neutrophils, and other white blood cells (Aderem, 2003). Phagocytosis is an essential part of the host immune response and is the first step to eliminate many invading

Table 4. Percentage of cells expressing specific molecules of dairy cows fed diets rich in n-3 or n-6 fatty acids (mean \pm SEM)

\begin{tabular}{|c|c|c|c|c|c|c|c|c|c|c|}
\hline \% Positive cells & \multicolumn{4}{|c|}{$\operatorname{Diet}^{1}$} & \multicolumn{6}{|c|}{$P$-value ${ }^{2}$} \\
\hline \multicolumn{11}{|l|}{$\overline{\mathrm{CD} 4^{+}}$} \\
\hline Postpartum & $11.1 \pm 1.24$ & $16.3 \pm 1.85$ & $12.2 \pm 1.60$ & $9.1 \pm 1.67$ & 0.043 & 0.002 & 0.542 & 0.009 & 0.039 & 0.656 \\
\hline \multicolumn{11}{|l|}{$\mathrm{CD} 8^{+}$} \\
\hline Prepartum & $8.4 \pm 1.25$ & $10.6 \pm 1.30$ & $10.3 \pm 2.52$ & $9.7 \pm 1.40$ & 0.938 & 0.468 & 0.915 & 0.567 & 0.866 & 0.843 \\
\hline \multicolumn{11}{|l|}{$\Gamma \delta$} \\
\hline Prepartum & $47.5 \pm 0.07$ & $42.3 \pm 0.03$ & $29.2 \pm 0.05$ & $47.0 \pm 0.04$ & 0.615 & 0.201 & 0.986 & 0.498 & 0.233 & 0.736 \\
\hline Postpartum & $42.2 \pm 0.03$ & $40.2 \pm 0.07$ & $36.2 \pm 0.05$ & $38.0 \pm 0.08$ & 0.209 & 0.162 & 0.325 & 0.149 & 0.740 & 0.116 \\
\hline \multicolumn{11}{|l|}{$\mathrm{CD} 4^{+}$} \\
\hline Prepartum & $21.6 \pm 1.39$ & $18.2 \pm 0.89$ & $30.6 \pm 0.85$ & $25.1 \pm 0.81$ & 0.023 & 0.758 & 0.682 & 0.810 & 0.035 & 0.486 \\
\hline Postpartum & $18.9 \pm 1.23$ & $11.2 \pm 1.19$ & $24.4 \pm 1.10$ & $22.3 \pm 1.08$ & 0.001 & 0.508 & 0.237 & 0.761 & 0.008 & 0.203 \\
\hline \multicolumn{11}{|l|}{$\mathrm{CD}^{2} 5^{+}(\alpha-\mathrm{IL}-2)$} \\
\hline Prepartum & $6.5 \pm 0.97$ & $9.8 \pm 0.94$ & $10.0 \pm 0.92$ & $8.5 \pm 0.77$ & 0.633 & 0.483 & 0.361 & 0.224 & 0.644 & 0.823 \\
\hline
\end{tabular}

${ }^{1} \mathrm{CON}=$ control, $\mathrm{WF}=$ whole flaxseed $(\mathrm{n}-3 \mathrm{FA}$ source), WS $=$ whole raw soybean $(\mathrm{n}-6 \mathrm{FA}$ source), and CSFA $=$ calcium salts of fatty acids (n-6 FA source).

${ }^{2}$ Time (days), INT $=$ diet $\times$ time, $\mathrm{C} 1=\mathrm{CON}$ vs. diets with supplemental fat, $\mathrm{C} 2=\mathrm{WF}$ vs. WS + CSFA, and C3 $=\mathrm{WS}$ vs. CSFA. 
pathogens. After destruction of the pathogens, phagocytic cells can generate peptides that may be presented, in conjunction with major histocompatibility complex, to $\mathrm{T}$ cells to initiate the adaptive immune response to the pathogen (Calder, 2007). Fat supplementation increased the percentage of leukocytes positive for phagocytosis, mainly due to the increased percentage of monocytes positive for phagocytosis, while the percentage of neutrophils positive for phagocytosis was not altered. Calder (1998) demonstrated in an in vitro study that alterations in phagocyte membrane FA composition are related to altered phagocytic capacity. The exact intracellular mechanisms involved in improved phagocytic capacity are not yet clear, but Calder et al. (1990) suggested that PUFA alter the expression of receptors involved in phagocytosis and change the physical nature of the membrane. Indeed, studies reported that unsaturated FA increased phagocytosis capacity (Calder et al., 1990; de Pablo et al., 1998).

In the current experiment, there was a clear increase in the percentage of leukocytes that were positive for phagocytosis in cows fed WF compared with WS or CSFA; however, it seems unlikely that this difference was solely related to the FA profile of diets. Ketone body concentrations are known to impair the phagocytic and bactericidal capacity of neutrophils (Suriyasathaporn et al., 1999). Furthermore, glucose has been shown to be the preferred metabolic fuel during an immune response for activated neutrophils, macrophages, and lymphocytes rather than FA, amino acids, or ketone bodies (Barghouthi et al., 1995; Gamelli et al., 1996; Pithon-Curi et al., 2004). An example was described by Lang and Dobrescu (1991), who observed decreased phagocytic capability in murine macrophages that had uptake of glucose inhibited by insulinopenic condition.

Increasing the capacity for phagocytosis does not necessarily indicate an improvement in immune system function, because leukocytes must be activated to release protein and lipid mediators and produce reactive oxygen and nitrogen species to eliminate the pathogen. Fat supplementation increased the median fluorescent intensity of monocytes but not of neutrophils. Anes et al. (2003) reported that several cellular lipids (arachidonic acid-derivative of C18:2 FA, ceramide, and sphingosine) can stimulate actin nucleation around phagosomes and cause subsequent fusion of the phagosomes with late endocytic organelles in macrophages infected with mycobacteria, suggesting that these lipids may enhance pathogen killing. In addition, arachidonic acid may be formed in ruminants from C18:2 FA by specific enzymes and can be used for biosynthesis of eicosanoids including thromboxane, lipoxins, leukotrienes, prostacyclins, and prostaglandins. These eicosanoids are signaling molecules that can trigger a proinflamma- tory response, depending on their expression (Sordillo et al., 2009). Several key aspects of immune response, such as cytokine production, cell proliferation, and antigen presentation are regulated by eicosanoids (Harizi et al., 2008).

In the current experiment, we did not detect an increase in median fluorescence intensity in the neutrophils of cows fed supplemental FA. In contrast, Kew et al. (2003) observed a positive correlation between the phagocytic activity of both neutrophils and monocytes with the content of n-3 and n-6 FA in human diets. However, we did observe greater leukocyte activity when cows were fed WF compared with WS or CSFA. According to Lopes et al. (1999), diets rich in n-6 FA are associated with lower superoxide and hydrogen peroxide production by stimulated neutrophils.

The immune system is usually depressed from approximately 3 wk before calving until 3 wk after calving (Mallard et al., 1998). In the current study the percentage of leukocytes that were positive for phagocytosis decreased from 1 wk before calving, whereas the phagocytotic intensity and activity decreased from 4 wk before calving. This observation may be related to blood glucose concentrations, which decreased during the entire prepartum period in our experiment. Other studies (Revelo and Waldron, 2010; Silvestre et al., 2011; Ster et al., 2012) observed decreased phagocytotic intensity of leukocytes, monocytes, and neutrophils when cows were close to calving and during the first week postpartum, similar to the results found in the present study.

In addition to the involvement of the innate immune system, several other cells and molecules participate in the complete immune response in mammals, including lymphocytes (adaptive immunity) and adhesion molecules expressed in leukocytes.

The T-lymphocytes are subdivided into helper Tlymphocytes (Th-lymphocytes) and cytotoxic T-lymphocytes, which express CD4 or CD8 molecules, respectively, on their surface. T-lymphocytes can recognize and respond to the peptide antigens that are linked to major histocompatibility complex proteins on the surface of antigen presenting cells to further activate the adaptive immune response. The adaptive response is composed of T-lymphocyte proliferation and differentiation and activation of B-lymphocytes, natural killer cells, and macrophages (Calder et al., 2002).

The Th-lymphocytes are classified and regulated based on the cytokines that they produce: Th1 cells produce IL-2 and IFN- $\gamma$, which activate macrophage, natural killer cells, and cytotoxic cells; Th2 cells produce IL-4 (related to IgE production), IL-5 (eosinophil activating factor), and IL-10 (which together with IL-4 suppresses cell-mediated immunity and inflammation); and Th17 cells produce IL-17 and IL-17F (proinflam- 
matory cytokines). Other classes of Th cells have been described (Mosmann and Sad, 1996), but they were not the focus of the present experiment. Cytotoxic T-lymphocytes are involved with destruction of cells infected with viruses.

In spite of a clear increase in $\mathrm{CD}^{+}$and $\mathrm{CD} 8^{+}$cells in response to supplemental FA, the interpretation of exactly how increased Th-lymphocytes will alter the immune response is complex, because they can either stimulate or suppress cell-mediated immunity. However, an analysis of both the changes in Th-lymphocytes and the phagocytotic activity of leukocytes seems to suggest a proinflammatory effect of FA supplementation in transition cows. Moreover, cows fed WF had greater expression of $\mathrm{CD}^{+}$than cows fed WS and CSFA, demonstrating a potentially greater proinflammatory actions of n-3 compared with n- 6 FA. On the other hand, some studies indicate that PUFA, especially those of the n-3 family, have immunosuppressive effects on both innate and adaptive immunity in mice and humans (Shaikh and Edidin, 2006).

The differences in the magnitude or nature of the effects of n-3 FA on the immune system may be related to the concentrations of these FA that eventually circulate in the bloodstream after FA supplementation. For example, PUFA at low concentrations were found to be necessary for lymphocyte proliferation, but at greater concentrations, PUFA inhibited proliferation (Karsten et al., 1994; Robinson and Field, 1998).

Expression of adhesion molecules on migrating cells and on endothelial cells can regulate leukocyte recruitment (von Andrian and Mackay, 2000). Recruitment of leukocytes into areas of inflammation begins with the binding of white blood cells to endothelium, followed by their transmigration into tissues (Albelda et al., 1994). The selectin family of adhesion molecules mediates the initial attachment of leukocytes to endothelial cells, which allows leukocytes to roll along the venular wall (Lasky, 1992; Bevilacqua and Nelson, 1993). Subsequently, members of the integrin and immunoglobulin superfamily interact to arrest leukocyte rolling and mediate the firm adhesion between leukocyte and the vascular endothelium.

The CD25 adhesion molecule is a subunit of the IL-2 receptor (related with regulatory T-cells and NK cells), is upregulated by lymphocyte stimulation (Chastagner et al., 1996), and is expressed on activated T-cells and monocytes (Foote et al., 2005). Supplementation of PUFA has been found to decrease the expression of IL-2 receptor in a previous study (Soyland et al., 1994). In contrast, our study demonstrated greater expression of CD25 when cows were fed supplemental FA. The IL-2 receptor is expressed in response to an interaction of the antigen and major histocompatibility complex
(Minami et al., 1993). Activation of intracellular signal transduction pathways after binding of IL-2 to the IL-2 receptor results in cellular proliferation (Waldmann, 1989).

L-selectin (CD62L) is an adhesion molecule found in lymphocytes and other cells, including neutrophils and monocytes. A study using CD62L knockout mice demonstrated that CD62L has a role in lymphocyte homing to lymphoid tissues and to sites of inflammation (Arbones et al., 1994). In the current study, supplemental FA increased the expression of CD62L adhesion molecule. Similarly, Silvestre et al. (2011) reported increased expression of CD62L molecules on mononuclear cells when transition cows were fed PUFA compared with saturated FA. The effect of dietary FA on L-selectin expression is likely due to the nutraceutical, rather purely energetic, properties of dietary FA, because expression of CD62L in circulating leukocytes from adult cattle is not affected by energy balance (Perkins et al., 2001). Thus, PUFA may improve immune response by favoring lymphocyte migration to injury sites.

Finally, cows fed WS showed lower expression of CD14 molecule when compared with cows fed WS and CSFA. Molecule CD14 is recognized as a pattern recognition receptor for a variety of ligands, including apoptotic cells, fungi, bacterial products (LPS, endotoxin), and even whole bacteria (Devitt et al., 1998). This result may indicate that feeding n-6 FA may increase recognition of gram-negative bacteria by monocytes.

\section{CONCLUSIONS}

Our results are consistent with the idea that PUFA supplementation can modulate innate and adaptive cellular immunity by increasing phagocytic capacity and activity of monocytes and by increasing the expression of adhesion molecules in T-lymphocytes. Furthermore, an increase of expression of adhesion molecules in response to PUFA supplementation suggests a proinflammatory effect of PUFA in transition dairy cows. The n-3 FA seems to have a greater effect on phagocytic capacity and activity of leukocytes as compared with n-6 FA.

\section{ACKNOWLEDGMENTS}

The authors express their appreciation to the Dairy Cattle Research Laboratory (Pirassununga, SP, Brazil) staff. The authors thank the financial support of Sao Paulo Research Foundation (FAPESP, Sao Paulo, SP, Brazil; grant \#2009/10180-0 and grant \#2011/07726$1)$. 


\section{REFERENCES}

Aderem, A. 2003. Phagocytosis and the inflammatory response. J. Infect. Dis. 187(Suppl. 2):S340-S345.

Albelda, S. M., C. W. Smith, and P. A. Ward. 1994. Adhesion molecules and inflammation injury. FASEB J. 8:504-512.

Allen, M. S. 2000. Effects of diet on short-term regulation of feed intake. J. Dairy Sci. 83:1598-1624.

Anes, E., M. P. Kühnel, E. Bos, J. Moniz-Pereira, A. Haberman, and G. Griffiths. 2003. Selected lipids activate phagosome actin assembly and maturation resulting in killing of pathogenic mycobacteria. Nat. Cell Biol. 5:793-802.

Arbones, M. L., D. C. Ord, K. Ley, H. Ratech, C. Maynard-Curry, D. J. Capon, and T. F. Tedder. 1994. Lymphocyte homing and leukocyte rolling and migration are impaired in L-selectin-deficient mice. Immunity 1:247-260.

AOAC International. 2000. Official Methods of Analysis. Vol. II. 17th ed. AOAC Int., Arlington, VA.

Barghouthi, S., K. D. Everett, and D. P. Speert. 1995. Nonopsonic phagocytosis of Pseudomonas aeruginosa requires facilitated transport of D-glucose by macrophages. J. Immunol. 154:3420-3428.

Bevilacqua, M. P., and R. M. Nelson. 1993. Endothelial-leukocyte adhesion molecules in inflammation and metastasis. Thromb. Haemost. 70:152-154.

Blagitz, M. G., F. N. Souza, B. P. Santos, C. F. Batista, A. C. Parra, L. F. F. Azevedo, P. A. Melville, N. R. Benites, and A. M. M. P. Della Libera. 2013. Function of milk polymorphonuclear neutrophil leukocytes in bovine mammary glands infected with Corynebacterium bovis. J. Dairy Sci. 96:3750-3757.

Brown, M., and C. Witter. 2000. Flow cytometry: Principles and clinical applications in hematology. Clin. Chem. 46:1221-1229.

Calder, P. C. 1998. Dietary fatty acids and lymphocyte functions. Proc. Nutr. Soc. 57:487-502.

Calder, P. C. 2006. n-3 polyunsaturated fatty acids, inflammation, and inflammatory diseases. Am. J. Clin. Nutr. 83(Suppl.):1505S1519S.

Calder, P. C. 2007. Immunomodulation by n-3 fatty acids. Prostaglandins Leukot. Essent. Fatty Acids 77:327-335.

Calder, P. C., J. A. Bond, D. J. Harvey, S. Gordon, and E. A. Newsholme. 1990. Uptake and incorporation of saturated and unsaturated fatty acids into macrophage lipids and their effect upon macrophage adhesion and phagocytosis. Biochem. J. 269:807-814.

Calder, P. C., P. Yaqoob, F. Thies, F. A. Wallace, and E. A. Miles. 2002. Fatty acids and lymphocyte functions. Br. J. Nutr. 87(Suppl. 1):S31-S48.

Chastagner, P., J. L. Moreau, Y. Jacques, T. Tanaka, M. Miyasaka, M. Kondo, K. Sugamura, and J. Thèze. 1996. Lack of intermediateaffinity interleukin-2 receptor alpha, beta and gamma chain expression for T cell growth. Eur. J. Immunol. 26:201-206.

de Pablo, M. A., E. Ortega, A. M. Gallego, C. Alvarez, P. L. Pancorbo, and G. Alvarez de Cienfuegos. 1998. The effect of dietary fatty acid manipulation on phagocytic activity and cytokine production by peritoneal cells from Balb/c mice. J. Nutr. Sci. Vitaminol. (Tokyo) 44:57-67.

Devitt, A., O. D. Moffat, C. Raykundalia, J. D. Capra, D. L. Simmons, and C. D. Gregory. 1998. Human CD14 mediates recognition and phagocytosis of apoptotic cells. Nature 392:505-509.

Foote, M. R., B. J. Nonnecke, M. A. Fowler, B. L. Miller, D. C. Beitz, and W. R. Waters. 2005. Effects of age and nutrition on expression of CD25, CD44, and L-selectin (CD62L) on T-cells from neonatal calves. J. Dairy Sci. 88:2718-2729.

Gamelli, R. L., H. Liu, L. K. He, and C. A. Hofmann. 1996. Augmentations of glucose uptake and glucose transporter-1 in macrophages following thermal injury sepsis in mice. J. Leukoc. Biol. 59:639-647.

Greco, L. F., J. T. Neves Neto, A. Pedrico, R. A. Ferrazza, F. S. Lima, R. S. Bisinotto, N. Martinez, M. Garcia, E. S. Ribeiro, G. C. Gomes, J. H. Shin, M. A. Ballou, W. W. Thatcher, C. R. Staples, and J. E. P. Santos. 2015. Effects of altering the ratio of dietary $\mathrm{n}-6$ to $\mathrm{n}-3$ fatty acids on performance and inflammatory response to a lipopolysaccharide challenge in lactation Holstein cows. J. Dairy Sci. 98:602-617.

Grummer, R. R. 2008. Nutritional and management strategies for the prevention of fatty liver in dairy cattle. Vet. J. 176:10-20.

Grummer, R. R., D. G. Mashek, and A. Hayirli. 2004. Dry matter intake and energy balance in the transition period. Vet. Clin. N. Am. Food Anim. 20:447-470.

Hammon, D. S., I. M. Evjen, T. R. Dhiman, J. P. Goff, and J. L. Walters. 2006. Neutrophil function and energy status in Holstein cows with uterine health disorders. Vet. Immunol. Immunopathol. 113:21-29.

Harizi, H., J. Corcuff, and N. Gualde. 2008. Arachidonic-acid derived eicosanoids: Roles in biology and immunopathology. Trends Mol. Med. 14:461-469.

Hart, K. A., M. H. Barton, M. L. Vandenplas, and D. J. Hurley. 2011. Effects of low-dose hydrocortisone therapy on immune function in neonatal horses. Pediatr. Res. 70:72-77.

Karsten, S., G. Schafer, and P. Schauder. 1994. Cytokine production and DNA synthesis by human peripheral lymphocytes in response to palmitic, stearic, oleic and linoleic acid. J. Cell. Physiol. 161:1522.

Kelley, D. S., and I. L. Rudolph. 2000. Effect of individual fatty acids of omega- 6 and omega-3 type on human immune status and role of eicosanoids. Nutrition 16:143-145.

Kew, S., T. Banerjeet, A. M. Minihane, Y. E. Finnegan, R. Muggli, R. Albers, C. N. Williams, and C. P. Calder. 2003. Lack of effect of foods enriched with plant- or marine-derived n-3 fatty acids on human immune function. Am. J. Clin. Nutr. 77:1287-1295.

Kimura, K., J. P. Goff, M. E. Jr. Kehrli, and T. A. Reinhardt. 2002 Decreased neutrophil function as a cause of retained placenta in dairy cattle. J. Dairy Sci. 85:544-550.

Lang, C. H., and C. Dobrescu. 1991. Sepsis-induced increases in glucose uptake by macrophage-rich tissues persist during hypoglycemia. Metabolism 40:585-593.

Lasky, L. A. 1992. Selectins: interpreters of cell-specific carbohydrate information during inflammation. Science 258:964-969.

Lichtenstein, A. H., and U. S. Schwab. 2000. Relationship of dietary fat to glucose metabolism. Atherosclerosis 150:227-243.

Littell, R. C., G. A. Milliken, W. W. Stroup, R. D. Wolfinger, and O. Schabenberger. 2006. SAS ${ }^{\circledR}$ for Mixed Models. 2nd ed. SAS Ins. Inc., Cary, NC.

Lopes, L. R., F. R. Laurindo, J. Mancini-Filho, R. Curi, and P. Sannomiya. 1999. NAPH-oxidase activity and lipid peroxidation in neutrophil from rats fed fat rich diets. Cell Biochem. Funct. 17:5764.

Mallard, B. A., J. C. Dekkers, M. J. Ireland, K. E. Leslie, S. Sharif, C. L. Vankampen, L. B. N. Wagter, and B. N. Wilkie. 1998. Alteration in immune responsiveness during the peripartum period and its ramification on dairy cow and calf health. J. Dairy Sci. 81:585-595.

Mallard, B. A., L. C. Wagter, M. J. Ireland, and J. C. Dekkers. 1997. Effects of growth hormone, insulin-like growth factor-i, and cortisol on periparturient antibody response profiles of dairy cattle. Vet. Immunol. Immunopathol. 60:61-76.

Mashek, D. G., S. J. Bertic, and R. R. Grummer. 2005. Effects of intravenous triacylglycerol emulsions on hepatic metabolism and blood metabolites in fated dairy cows. J. Dairy Sci. 88:100-109.

Miksa, M., H. Komura, R. Wu, K. G. Shah, and P. Wang. 2009. A novel method to determine the engulfment of apoptotic cells by macrophages using pHrodo succinimidyl ester. J. Immunol. Methods 342:71-77.

Minami, Y., T. Kono, T. Miyaki, and T. Tanigushi. 1993. The IL-2 receptor complex: Its structure, function, and target genes. Annu. Rev. Immunol. 11:245-268.

Mosmann, T. R., and S. Sad. 1996. The expanding universe of T-cell subsets: Th1, Th2 and more. Immunol. Today 17:138-146.

NRC. 2001. Nutrient Requirements of Dairy Cattle. 7th rev. ed. Natl. Acad. Press, Washington, DC.

Oliveira, L. J., and P. J. Hansen. 2008. Deviations in populations of peripheral blood mononuclear cells and endometrial macrophages in the cow during pregnancy. Reproduction 136:481-490. 
Perkins, K. H., M. J. VandeHaar, R. J. Tempelman, and J. L. Burton. 2001. Negative energy balance does not decrease expression of leukocyte adhesion or antigen presenting molecules in cattle. J. Dairy Sci. 84:421-428.

Pithon-Curi, T. C., M. P. De Melo, and R. Curi. 2004. Glucose and glutamine utilization by rat lymphocytes, monocytes and neutrophils in culture: A comparative study. Cell Biochem. Funct. $22: 321-326$.

Revelo, X. S., and M. R. Waldron. 2010. Effects of in vitro insulin and 2,4-thiazolidinedione on the function of neutrophils harvested from blood of cows in different physiological states. J. Dairy Sci. 93:3990-4005.

Robinson, L. E., and C. J. Field. 1998. Dietary long-chain (n-3) fatty acids facilitate immune cell activation in sedentary, but not exercise-trained rats. J. Nutr. 128:498-504.

Shaikh, S. R., and M. Edidin. 2006. Polyunsaturated fatty acids, membrane organization, T cells, and antigen presentation. Am. J. Clin. Nutr. 84:1277-1289.

Silvestre, F. T., T. S. Carvalho, N. Francisco, J. E. P. Santos, C. R. Staples, T. C. Jenkins, and W. W. Thatcher. 2011. Effects of differential supplementation of fatty acids during the peripartum and breeding periods of Holstein cows: II. Neutrophil fatty acids and function, and acute phase proteins. J. Dairy Sci. 94:2285-2301.

Sordillo, L. M., G. A. Contreras, and S. L. Aitken. 2009. Metabolic factors affecting the inflammatory response of periparturient dairy cows. Anim. Health Res. Rev. 10:53-63.

Soyland, E., T. Lea, B. Sandstad, and A. Drevon. 1994. Dietary supplementation with very long-chain n-3 fatty acids in man decreases expression of the interlekin-2 receptor (CD25) on mitogen-stimulated lymphocytes from patients with inflammatory skin diseases. Eur. J. Clin. Invest. 24:236-242.

Ster, C., M. C. Loiselle, and P. Lacasse. 2012. Effect of postcalving serum nonesterified fatty acids concentration on the functionality of bovine immune cells. J. Dairy Sci. 95:708-717.

Storlien, L. H., A. B. Jenkins, D. J. Chisholm, W. S. Pascoe, S. Khouri, and E. W. Kraegn. 1991. Influence of dietary fat composition on development of insulin resistance in rats. Relationship to muscle triglyceride and $\omega$-3-fatty acids in muscle phospholipid. Diabetes 40:280-289.
Storlien, L. H., E. W. Kraegen, D. J. Chisholm, G. L. Ford, D. G. Bruce, and W. S. Pascoe. 1987. Fish oil prevents insulin resistance induced by high fat feeding in rats. Science 237:885-888.

Sukhija, P. S., and D. L. Palmquist. 1988. Rapid method for determination of total fatty-acid content and composition of feedstuffs and feces. Agric. Food Chem. 36:1202-1206.

Suriyasathaporn, W., A. J. Daemen, E. N. Noordhuizen-Stassen, S. J. Dieleman, M. Nielen, and Y. H. Schukken. 1999. Beta-hydroxybutyrate levels in peripheral blood and ketone bodies supplemented in culture media affect the in vitro chemotaxis of bovine leukocytes. Vet. Immunol. Immunopathol. 68:177-186.

Turvey, S. E., and D. H. Broide. 2010. Innate immunity. J. Allergy Clin. Immunol. 125(Suppl. 2):S24-S32.

Van Soest, P. J., J. B. Robertson, and B. A. Lewis. 1991. Methods of dietary fiber, neutral detergent fiber, and nonstarch polysaccharides in relation to animal nutrition. J. Dairy Sci. 74:3583-3597.

von Andrian, U. H., and C. R. Mackay. 2000. T-cell function and migration. Two sides of the same coin. N. Engl. J. Med. 343:10201034 .

Waldmann, T. A. 1989. The multisubunit interleukin-2 receptor. Annu. Rev. Biochem. 58:875-911.

Weber, P. S., S. A. Madsen, G. W. Smith, J. J. Ireland, and J. L. Burton. 2001. Pretranslational regulation of neutrophil L-selectin in glucocorticoid-challenged cattle. Vet. Immunol. Immunopathol. $83: 213-240$.

Weiss, W. P., H. R. Conrad, and N. R. St. Pierre. 1992. A theoretically based model for predicting total digestible nutrient values of forages and concentrates. Anim. Feed Sci. Technol. 39:95-110.

Wiggins, M. C., A. R. Woolums, D. J. Hurley, S. Sanchez, D. T. Ensley, and D. C. Donovan. 2011. The effect of various Mycoplasma bovis isolates on bovine leukocyte responses. Comp. Immunol. Microbiol. Infect. Dis. 34:49-54.

Wildman, E. E., G. M. Jones, P. E. Wagner, and R. L. Boman. 1982. A dairy body condition scoring system and its relationship to selected production characteristics. J. Dairy Sci. 65:495-501.

Yaqoob, P. 2004. Fatty acids and the immune system: From basic science to clinical application. Proc. Nutr. Soc. 63:89-104. 